\title{
Findings From the Merci Mon Héros Social Listening Endline Report
}

Nov $2019-J a n 2021$ 


\section{Acknowledgments}

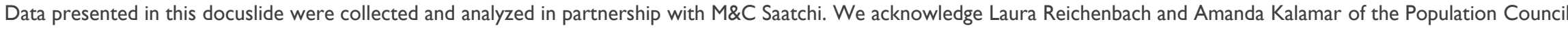

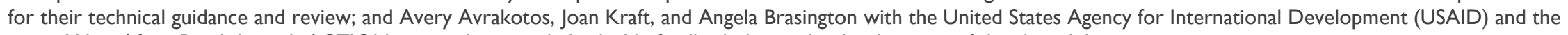
entire West Africa Breakthrough ACTION team, who provided valuable feedback during the development of this docuslide.

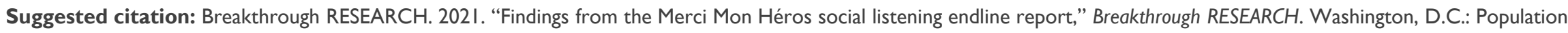
Council.

Breakthrough RESEARCH is made possible by the generous support of the American people through the United States Agency for International Development (USAID) under the terms of

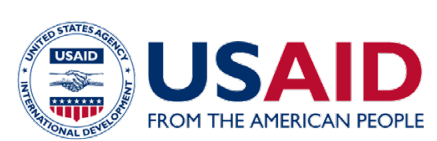

cooperative agreement no. AID-OAA-A-17-00018.

The contents of this document are the sole responsibility of the Breakthrough RESEARCH and Population Council and do not necessarily reflect the views of USAID or the United States Government.

Breakthrough RESEARCH catalyzes social and behavior change (SBC) by conducting state-of-the-art research and evaluation and promoting evidence-

\section{Breakthrough RESEARCH FOR SOCIAL \& BEHAVIOR CHANGE}

based solutions to improve health and development programs around the world. Breakthrough RESEARCH is a consortium led by the Population Council in partnership with Avenir Health, ideas42, Institute for Reproductive Health at Georgetown University, Population Reference Bureau, and Tulane University.
The Population Council confronts critical health and development issues - from stopping the spread of HIV to improving reproductive health and ensuring that young people lead full and productive lives. Through biomedical, social science and public health research in about 50 countries, the Council works with our partners to deliver solutions that lead to more effective policies, programs, and technologies to improve lives worldwide. Established in 1952 and headquartered in New York, the Council is a nongovernmental, nonprofit organization with an international board of trustees.

As stewards of the first school of public health in the United States, the Tulane University School of Public Health and Tropical Medicine cultivates independent thinkers, innovative leaders, fierce advocates and accomplished scholars. From the neighborhoods of New Orleans to communities worldwide, we conduct research and collaborate with our partners to ensure that all of humanity has an equitable opportunity to be healthy and pursue well-being. We train the problem solvers. Find us on the Front Lines. 


\section{Table of Contents}

Study overview _ $\quad 4$

Process \& methodology $\quad 8$

Study limitations _ $\quad 15$

Topline findings $\ldots$

RH/FP topic overview _ _ $\quad 22$

Menstruation/puberty _._._. 25

Merci Mon Héros findings $\quad 30$

Côte d'lvoire _ _ 33

Burkina Faso

Togo $\quad 5 \mathrm{I}$

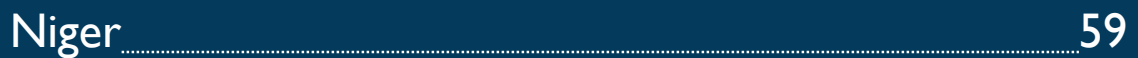




\section{Study Overview}

November 2019 - January 2021 


\section{Introduction to the study}

\section{The Merci Mon Héros campaign}

Merci Mon Héros (MMH), or Thank You My Hero in French, is a Breakthrough ACTIONimplemented mass media campaign targeting youth and adult allies, with the aim of promoting an environment conducive to young people's access to family planning (FP) and reproductive health $(\mathrm{RH})$ services in the four West Africa Breakthrough ACTION countries.

The youth-led campaign has released videos via social media platforms, including Facebook, Instagram, Twitter, and YouTube, as well as more traditional channels, such as television, radio, community screening events, and youth groups. Online content was released on a weekly basis at the beginning of the campaign, and other online events such as quizzes were gradually added to the social media feed.

\section{The study}

Breakthrough RESEARCH, through Tulane University and partner M\&C Saatchi, is assessing MMH through three separate activities: (I) social listening and social media monitoring,

(2) qualitative analysis, and (3) cost analysis. The results of these activities informed adaptive management of $\mathrm{MMH}$, as well as future related programs. These activities will be complemented with routine monitoring surveys conducted by Breakthrough ACTION during the campaign.

Social listening was used to assess online conversations at baseline (October 2018-October 20I9), followed by six social media monitoring reports that were conducted throughout the MMH campaign (November 2019-January 202I).

The overall aim of this report is to apply social listening to understand the potential impact of the campaign on the broader topic-relevant conversation online in four key countries: Côte d'Ivoire, Burkina Faso, Togo, and Niger. This report focuses on one key theme of six explored in the baseline report-menstruation \& puberty, and investigates how, if at all, that conversation has shifted during the endline period, I Nov 2019-3I Jan 202I. 


\section{Menstruation \& puberty}

Throughout the MMH campaign several campaign video posts and Facebook Live (FB Live) sessions were published specifically addressing the topic of menstruation and puberty.

The periodic MMH monitoring reports revealed posts around this topic to typically generate the highest engagement* among the topics addressed by the campaign videos and to resonate the most across our four target countries.

This engagement was achieved primarily on the campaign's public Facebook page, but the extent of engagement (i.e., total number of likes, comments, and shares) around this topic (relative to other topics), suggests that themes discussed in these videos would have the greatest chance of impacting the broader conversation across other social channels.

\section{menstruation}

\& puberty?

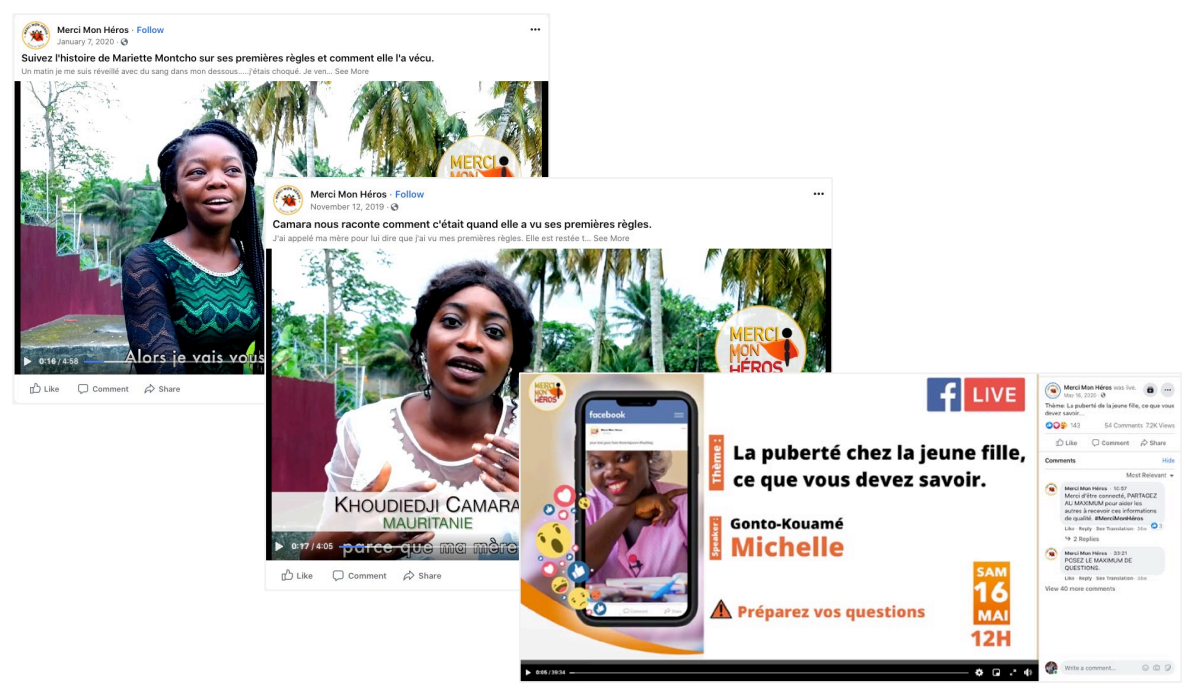




\section{Select}

\section{campaign videos}

The table below present a sample of the MMH campaign videos and Facebook Live events included in the campaign summary report, with those touching on the topic of puberty or menstruation in bold.

\begin{tabular}{|c|c|}
\hline Video & Primary messages \\
\hline Gracian & Talk about sexuality without shame from a very early age to be "sexually healthy" \\
\hline Camara & $\begin{array}{l}\text { Preparing young women for menstrual onset with accurate } \\
\text { information }\end{array}$ \\
\hline Florence & Use a condom during sex to avoid risk of STIs like HIV \\
\hline Mariette & $\begin{array}{l}\text { Normalizing and supporting young girls during menstrual onset to } \\
\text { avoid trauma }\end{array}$ \\
\hline Serge & Talking with youth about life projects/priorities for a healthy future \\
\hline Fanta & $\begin{array}{l}\text { Providing accurate information to young people about the onset of } \\
\text { menstruation }\end{array}$ \\
\hline Oury & Informing youth about family planning options to avoid unintended pregnancy \\
\hline Kouamé & $\begin{array}{l}\text { Encouraging young people to visit a health provider to learn more about } \\
\text { contraceptive methods }\end{array}$ \\
\hline Sedjro & Partner communication and decision making about FP \\
\hline $\begin{array}{l}\text { Mme } \\
\text { Comara }\end{array}$ & Managing contraceptive methods to plan pregnancies \\
\hline Aichatou & Encouraging parents to speak openly with young people about sexual and RH \\
\hline $\begin{array}{l}\text { Facebook } \\
\text { live events }\end{array}$ & $\begin{array}{l}\text { - Female puberty } \\
\text { - Male puberty } \\
\text { - The menstrual cycle and how to calculate the fertile window }\end{array}$ \\
\hline
\end{tabular}


Process \& Methodology 


\section{Social listening approach}

\section{Social listening}

Social listening is the process of tracking and analyzing conversation content and related metrics for a topic, program, or brand on social media. Social listening requires the identification of relevant conversation keywords (in multiple languages) and the crafting of a Boolean search string to capture the most relevant online posts.

\section{Identifying conversation keywords}

For the baseline understanding report, a robust set of relevant and appropriate keywords were identified in order to ensure the RH/FP discussion was properly represented in the social listening analysis. Words central to the conversation including (but not limited to), "menstruation," "puberty," and "period" were identified.

Due to the nature of social media and online conversation, as well as the somewhat sensitive nature of the RH/FP discussion, certain words carry a considerable volume of "noise" (irrelevant conversation). As such, the final list of words were subsequently crafted into a tailored Boolean search string, which was designed to eliminate as much noise as possible.

The full list of selected English keywords were subsequently translated into French. Acknowledging the importance of local slang and vernacular, feedback from each country was also sought and obtained. Local language keywords were subsequently built into the final search string to ensure robustness and accuracy of results. 


\section{Isolating sub-topics}

Leveraging machine learning software

Crimson Hexagon is a market-leading social listening platform that enables users to track conversation content and related metrics for a topic, program, or brand on social media. By leveraging Crimson Hexagon's machine learning algorithm, "Brightview," we were able to train the algorithm to classify social posts based on the topic the posts primarily related to. The machine learning software then analysed the remaining untrained posts and classified them accordingly, based on the language detected in the posts. This resulted in a breakdown of the conversation into overarching topics and a subsequent uncovering of key trends, volume of conversation, attitudes, and more.

During the baseline understanding report, posts were assigned against six key areas. For the endline report, the focus was solely on menstruation/puberty as videos addressing this topic garnered by far the greatest engagement* and therefore had the greatest potential for impact.

\section{Social posts assigned against 6 key areas}

Sexual behavior \& contraception

Sexism \& gender

Menstruation/puberty

Sex \& relationships

Sexually transmitted infections

\section{Sexual violence}

Irrelevant conversation 


\section{Categorizing sub-topics}

\section{Categorizing sub-topics}

Within menstruation/puberty, three key themes were identified in the baseline report as being central to the sub-topic conversation. These were: "first periods," "pain," and "support groups."

In this report, these themes were identified as a proportion of the overall sub-topic, based on the presence of applicable keywords across the corpus of social media posts. For example, the theme of pain was identified by searching for any words related to pain (e.g., pain, sore, and cramps), posted in conjunction with words related to the menstruation/puberty subtopic.

This approach allowed us to determine the proportion of sub-topic specific posts that were directly attributable to each of the key themes. It should be noted that one single post could sit across all three themes, depending on the content of the post.

The research team seeks to understand whether these key themes grew or declined in importance, by determining the proportional increase/decrease in posts featuring keywords related to these themes.

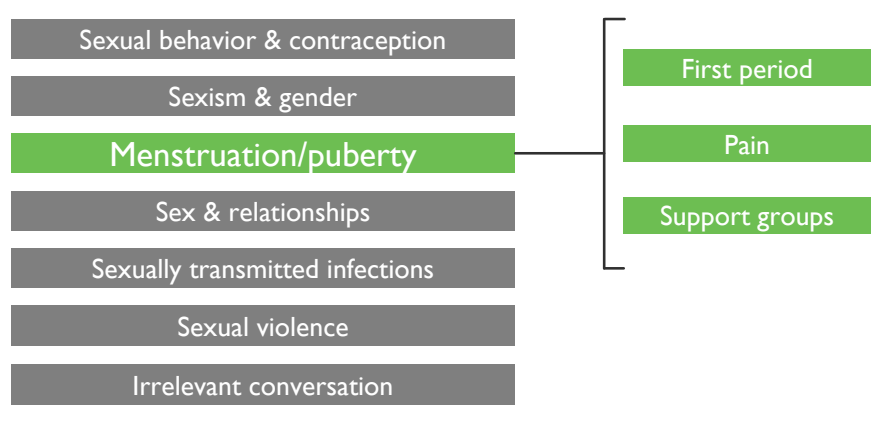




\section{Analytical approach}

\section{Study questions}

Two study questions have guided this report:

I. Did the online conversation in the four focus countries change between the baseline period before the campaign was launched (October 2018-October 2019) and the campaign implementation period (November 2019-January 202I)?

2. To what extent are detected changes associated with the MMH campaign?

\section{Key definitions}

- Total conversation volume - the number of social media posts pertaining to a specific topic. These may include noise or irrelevant conversation that may contain key search terms but that are not considered relevant upon further inspection.

- Relevant conversation volume - the number of social media posts remaining after cleaning the data of irrelevant noise. Posts are assessed by reading content and assessing whether the post is not addressing the topic, despite mentioning the keyword.

\section{Approaches used}

Three main approaches are used to address the study aims:

I. Comparing topic specific relevant conversation volume at baseline and endline.

2. Plotting time trends for topic specific relevant conversation volume and $\mathrm{MMH}$ online content distribution.

3. Plotting local Google Trends search terms against MMH content distribution.

4. Thematic qualitative analysis of social media posts to provide context to the relevant conversation.

\section{Testing associations}

For this endline report, chi-square tests have been used to understand the statistical significance of changes in relevant conversation volume between the baseline period and the endline period. For the purposes of this report, statistical significance has been defined as $\mathrm{p}<0.05$. 


\section{Social media channels}

While some data can be tracked from Facebook, the vast majority of Facebook data is not accessible through social listening tools due to its privacy policy. Likewise, Instagram and WhatsApp data are also restricted by privacy rights and therefore inaccessible. For this analysis only the public-facing MMH campaign Facebook page could be included.

The analysis also draws on subject-relevant mentions on public facing social media platforms, including Twitter, YouTube comments, forums, blogs, Reddit, news channels, and Tumblr.

The chart below reflects the source breakdown of public facing data only.

\section{Sources of}

Conversation source breakdown

\section{conversation}

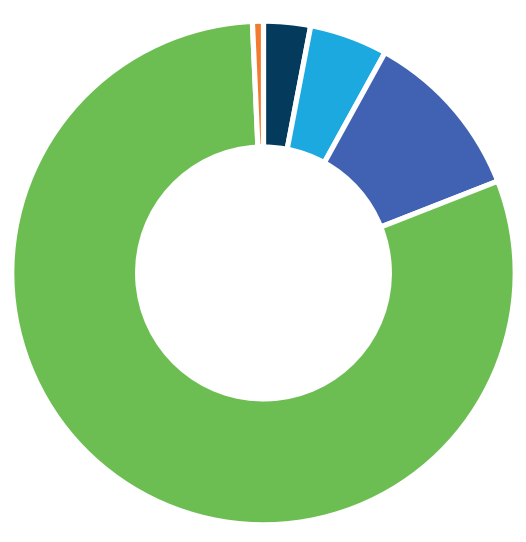

- Blogs (3\%)

- Forums (5\%)

- News (1 I\%)

- Twitter (80\%)

- Facebook ( $1 \%)$ 


\section{Detecting age on social media}

Detecting adult-youth communications on

\section{public-facing social media}

A core focus of the MMH campaign is to encourage and grow adult-youth communication around subjects considered to be taboo such as menstruation, puberty, and sexual behavior.

However, due to privacy limitations, social listening cannot detect age data linked to individuals posting comments. While age can be detected at an overall level, to understand the age breakdown of those participating in the conversation in the aggregate, it cannot be tracked in individual conversation threads.

As such, we are limited to using specific search terms such as "mom", "dad", "father", "mother", "daughter", "son", and "parents", to detect conversations happening between generations.

Additionally, the platforms themselves must be considered here too. Conversations, particularly of this nature, are far more likely to happen "behind closed doors" on other social platforms such as WhatsApp, FB Messenger, and Facebook walls. As mentioned previously, the data on these platforms is restricted and inaccessible for this analysis.

Rather, this report focuses on conversations on Twitter, forums, blogs, etc., where open dialogue is less common. This may result in a bias toward exchanges that include more normative opinions and perceptions. However, it is worth noting that although actual conversations may be more likely behind closed doors, thoughts, beliefs, attitudes, and anecdotes about communication might still be expressed in public forums, making this a valuable exercise. 


\section{Study Limitations}




\section{Internet users and social media access}

World Bank Data indicates that internet penetration rates vary considerably by each of the four countries under review. Côte d'Ivoire's internet penetration was estimated at approximately $47 \%$ in 2018 . This compares to approximately $16 \%, 12 \%$, and $10 \%$ in Burkina Faso, Togo, and Niger, respectively. Further, social media would be accessed by just a subset of the online population, with urban, socioeconomic, and education skews very likely. However, given that social media was one of the media of choice for the campaign implementation, potential biases posed by the methodology used for this study do not differ to those posed by the online campaign itself.

\section{Local language}

Despite every effort made to ensure that local language and vernacular are catered to in the analysis, the absence of a fluent local language analyst should be noted. It is our belief that the conversation is accurately represented through the application and classification of our carefully selected and translated keywords.

It is worth noting that for the limited English language comments that do impact the analysis, those commenting in English are likely not representative of people in the lower socioeconomic classes. Having said that, the same could potentially also be said for those with access to social media.

\section{Topic volumes}

Due to the highly nuanced nature of the conversation, topic volumes should not be viewed as complete or exhaustive. First, the search string has been created to minimize irrelevant conversation in the analysis, but naturally cannot be $100 \%$ effective. Second, some posts could feasibly sit across multiple topics, yet are assigned to just one in an effort to give a guideline quantification of the conversation.

That said, given that the same principles and classifications are applied consistently across the analysis, we are still able to view the results as representative of the total conversation.

\section{Topic sources}

The analysis has been designed to scrape* mentions of public facing social media platforms, including Twitter, YouTube comments, forums, blogs, Reddit, Pinterest, and Tumblr.

Notable exemptions from this list are Facebook, Instagram, and WhatsApp. Social listening tools such as Crimson Hexagon cannot track these sites due to their privacy policies. The only Facebook page that can be included in this analysis is the MMH campaign page. 


\section{Impact of Covid-19}

\section{Covid-1 9 impact on the conversation}

Covid-19 was a significant topic on social media during 2020. In the four core countries, Côte d'Ivoire, Burkina Faso, Togo, and Niger, there were a combined 359k+ mentions of Covid- 19 during the period I Jan 2020-3I Jan 202I.

The chart below tracks mentions of Covid- 19 across the four countries, showing a significant spike in each country during March 2020, correlating with the global outbreak of Covid-19/ stay-at-home orders. While conversation did decline thereafter, there was still consistent mention of Covid-19 throughout the rest of the year, particularly in the Côte d'Ivoire and Burkina Faso.

This has two implications for our study:

I. Around March/April, when lockdown orders and fear were at their peak, people were spending significantly more time online and on social media. As such, we might expect to see boosted volume of social media posts during this time.

2. Overall, with people talking so much about Covid-19, we might expect to see a mention volume decrease overall for other conversations.

\section{Covid-1 9 social posts across the four key countries}

4500
4000
3500
3000
2500
2000
1500
1000
500 
Topline Findings 
Overall

campaign findings
- Overall, direct mentions of the campaign on public facing social media channels remained very low throughout the review period. While the topics discussed in MMH content grew in volume share, direct attribution of this discussion to MMH content is not possible. The data points to correlational relationships, which show how in some countries social discussion coincided with MMH content, suggesting potential impact.

- Since the start of the campaign, the proportion of females taking part in the social discussion has increased in three of four countries. While the campaign supported female engagement, this change is likely attributable to a combination of factors, including shifting social norms and increased access and use of internet and social media. 


\section{Changes in the dialogue from baseline to endline}

\section{Menstruation/} puberty specific findings
- Across each country, menstruation/puberty share of overall RH/FP conversation increased since the beginning of the $\mathrm{MMH}$ campaign. Conversation volume related to menstruation/puberty increased by $8 \%$ in Côte d'Ivoire, $6 \%$ in Burkina Faso, $5 \%$ in Togo, and $2 \%$ in Niger.

- In both Côte d'Ivoire and Togo, we found a statistically significant difference when comparing conversation volume related to menstruation/puberty before and after publication of $\mathrm{MMH}$ content. In Burkina Faso and Niger, there was no discernible uptick in conversation volume following publication of $\mathrm{MMH}$ menstruation/puberty content.

- In both Côte d'Ivoire and Togo, there was a notable increase in post "replies" as a proportion of total comments. This suggests an increased willingness among the online population to engage in conversation relating to menstruation/puberty. This correlated with the publication of $\mathrm{MMH}$ content with increased volume of comments aligning with content release dates.

- Volume of conversation related to the menstruation/puberty topic was down during the endline review period. However, the volume of relevant conversation was up. This suggests more on-topic conversation during the endline period, as compared to the baseline. It should also be noted that the machine learning technology leveraged for these analyses is constantly learning. As such, while the same process was followed for both baseline and endline reviews, the machine will naturally have become more accurate over time as it understands the nuance within topic material.

- In Togo, where social media posts most notably reflected MMH campaign coverage on radio and television broadcast, it is noteworthy to see a $50 \%$ increase in the average weekly volume of cleaned menstruation/puberty posts.

- Data analysis reveals that countries experienced an increase in average weekly volume of relevant posts, coinciding with potential exposure to $\mathrm{MMH}$ content. When $\mathrm{MMH}$ achieves greater dissemination, the volume of relevant sub-topic posts increases. This was particularly true in Togo, where radio coverage and television broadcast was discussed on social media channels too. Programs should consider focusing on a multi-channel approach that leverages, television, radio, and social media. 


\section{Menstruation/} puberty content

\section{recommendations}

- In every country, the largest spike in menstruation/puberty conversations was driven by Menstrual Hygiene Day, 28 May 2020. Moving forward, MMH should create content around Menstrual Hygiene Day and other notable days in the calendar. Increasing the share of the campaign's voice around key events will ensure increased reach and awareness for campaign content.

- Across all countries, the puberty conversation was minimal in comparison to menstruation. Rather than focusing on the broader topic of puberty, programs should consider initiating conversations on puberty by first focussing on menstruation which may be a more common entry point to the conversation.

- In both Burkina Faso and Togo, there was a statistically significant increase for "sisters" being mentioned in the periods discussion. This refers to both familial sisters, as well as to the sense of female "sisterhood." This increased emphasis on the role of sisters/ sisterhood in the menstruation conversation offers an opportunity for $\mathrm{MMH}$. Future content should leverage this by championing the role of sisters/sisterhood in learning about menstruation.

- Across all countries, a significant theme of conversation relates to the pain associated with periods. This emphasis on pain in the dialogue offers an obvious route for $M M H$ to further enhance engagement by producing content that addresses this experience and provides tips on managing pain or in the case when the pain is severe encourages the audience to consult a healthcare professional. 


\section{RH/FP Topic Overview}

RH/FP sub-topic conversations | Baseline vs. endline 


\section{Sub-topic conversation volume share from baseline to endline}

\section{Topline overview for I Nov 20 I9-3 I Jan 202 I}

The tables show the relative size of each of the six key sub-topic areas in the broader conversation during both the baseline and endline reports.

Across all four countries the menstruation/puberty and sex \& relationships sub-topics grew in volume (proportionally), accounting for a larger volume share of the broader RH/FP social conversation.

Menstruation/puberty is the main area of focus for this report. This was a particularly resonant theme within the $\mathrm{MMH}$ content suggesting that the campaign may have played a part in the growth seen in this conversation.
However, it should also be noted that Menstrual Hygiene Day received greater engagement in 2020 vs previous years as numerous other organisations continue to contribute to the normalising of menstrual health conversations.

Growth in the sub-topic could potentially be correlated to an increasing acceptance of (and exposure to) the topic.

However, it is also likely attributable to a combination of other factors, including shifting social norms, but also increased access and use of internet and social media, rather than any single campaign.
Sub-topic

Menstruation/puberty

Sexism \& gender

Sexually transmitted infections

Sexual behavior \& contraceptive use Sexual violence

Sex \& relationships

\section{Sub-topic}

Menstruation/puberty

Sexism \& gender

Sexually transmitted infections

Sexual behavior \& contraceptive use

Sexual violence

Burkina Faso Sex \& relationships

Sub-topic

Menstruation/puberty

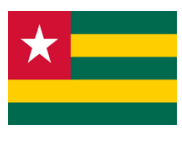

Sexism \& gender

Sexually transmitted infections

Sexual behavior \& contraceptive use

Sexual violence

Sex \& relationships

Sub-topic

Menstruation/puberty

Sexism \& gender

Sexually transmitted infections

Sexual behavior \& contraceptive use

Sexual violence

Niger

Sex \& relationships

\begin{tabular}{|c|c|c|}
\hline Baseline & Endline & $+/-\%$ Change \\
\hline $13 \%$ & $21 \%$ & $8 \%$ \\
\hline $33 \%$ & $21 \%$ & $-12 \%$ \\
\hline $7 \%$ & $5 \%$ & $-2 \%$ \\
\hline $15 \%$ & $12 \%$ & $-3 \%$ \\
\hline $10 \%$ & $16 \%$ & $6 \%$ \\
\hline $22 \%$ & $25 \%$ & $3 \%$ \\
\hline
\end{tabular}

\begin{tabular}{|c|c|c|}
\hline Baseline & Endline & $+1-\%$ Change \\
\hline $13 \%$ & $19 \%$ & $6 \%$ \\
\hline $34 \%$ & $29 \%$ & $-5 \%$ \\
\hline $9 \%$ & $8 \%$ & $-1 \%$ \\
\hline $16 \%$ & $8 \%$ & $-8 \%$ \\
\hline $11 \%$ & $10 \%$ & $-1 \%$ \\
\hline $17 \%$ & $23 \%$ & $6 \%$ \\
\hline
\end{tabular}

Baseline Endline +/- \% Change

\begin{tabular}{|c|c|c|}
\hline $13 \%$ & $18 \%$ & $5 \%$ \\
\hline $33 \%$ & $29 \%$ & $-4 \%$ \\
\hline $8 \%$ & $6 \%$ & $-2 \%$ \\
\hline $19 \%$ & $11 \%$ & $-8 \%$ \\
\hline $10 \%$ & $9 \%$ & $-1 \%$ \\
\hline $17 \%$ & $27 \%$ & $10 \%$ \\
\hline
\end{tabular}

\begin{tabular}{|c|c|c|}
\hline Baseline & Endline & $+\mathbf{+} \%$ Change \\
\hline $10 \%$ & $12 \%$ & $2 \%$ \\
\hline $33 \%$ & $31 \%$ & $-2 \%$ \\
\hline $9 \%$ & $6 \%$ & $-3 \%$ \\
\hline $27 \%$ & $23 \%$ & $-4 \%$ \\
$9 \%$ & $6 \%$ & $-3 \%$ \\
\hline $12 \%$ & $22 \%$ & $10 \%$ \\
\hline
\end{tabular}




\section{Three countries see female participation grow, but male skew}

\section{remains}

Topline overview for | Nov $20 \mid 9$ - 3 | Jan 202 ||

The baseline report revealed a heavy male skew in the gender identifiable

conversation around $\mathrm{RH} / \mathrm{FP}$. Gender is determined by social media account information when available and by leveraging artificial intelligence tools which detects gender based on social behavior (e.g., language used, interests, topics engaged with).

Although not statistically significant, three of the four countries experienced growth in the proportion of posts coming from female users during the endline review period.
The greatest growth was seen in Niger where there was a $6 \%$ growth in the number of women participating in the conversation. However, this country remains responsible for the greatest male skew.

In fact, all countries retain a heavy male skew, with access to social media still more widespread amongst males than females in these countries.

Further, the willingness to share opinions, behaviors, and beliefs on social media remains more widespread amongst males.

\section{GENDER BREAKDOWN OF TOPIC RELATED SOCIAL POSTS, BY COUNTRY}

\begin{tabular}{|c|c|c|c|c|c|c|c|c|c|c|c|c|}
\hline & \multicolumn{3}{|c|}{ Côte d'lvoire } & \multicolumn{3}{|c|}{ Burkina Faso } & \multicolumn{3}{|c|}{ Togo } & \multicolumn{3}{|c|}{ Niger } \\
\hline & Baseline & Endline & $\begin{array}{c}\% \\
\text { Change }\end{array}$ & Baseline & Endline & $\begin{array}{c}\% \\
\text { Change }\end{array}$ & Baseline & Endline & $\begin{array}{c}\% \\
\text { Change }\end{array}$ & Baseline & Endline & $\begin{array}{c}\% \\
\text { Change }\end{array}$ \\
\hline Male & $63 \%$ & $61 \%$ & $-2 \%$ & $58 \%$ & $63 \%$ & $+5 \%$ & $66 \%$ & $65 \%$ & $-1 \%$ & $81 \%$ & $75 \%$ & $-6 \%$ \\
\hline emale & $37 \%$ & $39 \%$ & $+2 \%$ & $42 \%$ & $37 \%$ & $-5 \%$ & $34 \%$ & $35 \%$ & $+1 \%$ & $19 \%$ & $25 \%$ & $+6 \%$ \\
\hline
\end{tabular}




\section{Menstruation/Puberty}

Sub-topic change over time | Baseline vs. endline | All countries 


\section{Volume of relevant menstruation/puberty conversation grew}

\section{MMH (I Nov 2019 - 3 I Jan 202 I)}

At a topline level, overall conversation around the menstruation/puberty topic was down during the endline review period, as indicated by the average weekly volume of posts.

However, when irrelevant noise was removed from the results, the volume of posts in the endline review period was greater than the baseline review.

The posts shown on the right, are an example of how certain posts might include mention of menstruation, periods, or puberty, but are considered to be irrelevant noise due to the actual content of the comment.
Once these types of mentions were removed, the average weekly volume of relevant posts increased from 23 to 30 , across the four core countries.

This suggests that while overall volume of conversation was down during the endline review period, the conversations were more on-topic.

\begin{tabular}{|c|c|c|}
\hline & $\begin{array}{c}\text { Baseline } \\
25 \text { Oct 2018-31 Oct } 2019\end{array}$ & $\begin{array}{l}\text { Endline } \\
\text { I Nov 2019-3 | Jan 2021 }\end{array}$ \\
\hline $\begin{array}{l}\text { Average weekly volume of menstruation/ } \\
\text { puberty topic posts }\end{array}$ & 516 & 379 \\
\hline $\begin{array}{l}\text { Average weekly volume of relevant } \\
\text { menstruation/puberty topic posts }\end{array}$ & 23 & 30 \\
\hline
\end{tabular}

\section{SAMPLE POST(S) INCLUDED IN TOTAL VOLUME BUT CONSIDERED IRRELEVANT}

*Quand tu avais tes premières règles, tu es allée dire ça à ta mère*

*Maintenant que ça ne vient plus, c'est à moi que tu viens dire $^{*} \approx$. Audrey, pourquoi tu es comme ça $\because \approx \approx$ ? ? \#PetitBiiscuit 9 ?

6:13 PM $\cdot 13$ mai 2020 depuis Côte d'Ivoire

(i)

\begin{tabular}{|l|} 
Menstruation ....... tu pleures \\
Romance ....... tu pleures \\
Sexe .......tu pleures \\
Accouchement ..... tu pleures \\
Mariage ....... tu pleures \\
rupture ..... tu pleures \\
Les filles quels sont exactement vos problèmes? \\
3:06 PM. 12 janv. 2019 \\
\hline$\bigcirc 793 \quad \bigcirc 513 \quad \mathcal{O}$ Copier le lien du Tweet \\
\hline
\end{tabular}

II sait quand tes règles commencent et finissent mais il ne sait pas quand tu as besoin d'argent. Ma sœur, que DIEU t'éloigne de ce gynécologue que tu appelles bb $\gg \leqslant$ \$s

6:17 PM · 18 nov. 2020
II sait quand tes règles commencent et finissent mais il ne sait pas quand tu as besoin d'argent. :- Ma sœur que Dieu t'éloigne de ce gynécologue que tu appelles BB. 11:30 AM - 12 sept. 2020

○ $57 \bigcirc 18$ \& Copier le lien du Tweet

*Duplication of posts highlights how certain jokes/messages proliferate and are posted separately by many different users 


\section{Each country saw an increase in average weekly relevant posts}

\section{MMH (I Nov 2019 - 30 July 2020)}

Findings on the previous page show us that the cleaned menstruation/puberty topic has increased overall since the beginning of the MMH campaign.

Here, we see the increase by country, based on the average weekly number of posts

(cleaned). The average weekly figure is used to account for

different review period lengths. Numbers relating to the overall volume of posts at endline are presented in the summary slide for each country.

In Togo, the radio and television broadcast coverage achieved by the campaign was well supported with social media posts celebrating the broadcast coverage. As such, it is noteworthy to see a $50 \%$ increase in the average weekly volume of cleaned menstruation/ puberty posts in this country.
Likewise, positive increases in the volume of relevant, average weekly posts around this topic were seen in each of the four countries.

Niger had the largest increase in average weekly posts (+100\%), but it should be noted that this represented growth from an average of I post per week to 2 .

From this, we can extrapolate a correlational relationship between campaign coverage and shifts in the volume of conversation around menstruation/puberty in-country.

However, again it should be noted that the continued efforts of other organisations and an increasing acceptance of and exposure to the topic are also key factors in this growth.

\section{CHANGE IN RELEVANT MENSTRUATION/PUBERTY CONVERSATION | ENDLINE VS BASELINE}

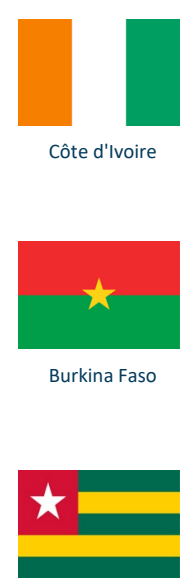

Togo
$29 \%$ increase in average weekly menstruation/puberty posts

$17 \%$ increase in average weekly menstruation/puberty posts

$50 \%$ increase in average weekly menstruation/puberty posts

$100 \%$ increase in average weekly menstruation/puberty posts 


\section{Menstrual Hygiene Day drives biggest spike in conversation}

\section{MMH (| Nov 20|9-3| Jan 202|)}

Menstrual Hygiene Day on 28 May 2020, drove the highest spike in conversation seen across the review period. This was driven by organisations spreading awareness of the event, as well as by individuals in each country sharing their stories and personal experiences relating to menstrual hygiene.

The significant impact of this day on the broader conversation highlights the importance of these events.

MMH does not seem to have effectively leveraged this day in 2020. Creating content that aligns with Menstrual Hygiene Day 202 I could potentially generate increased awareness through greater exposure.

\section{VOLUME OF RELEVANT MENSTRUATION/PUBERTY CONVERSATION | ENDLINE REPORT | NOV 2019 - JAN 202 I}

250
Menstrual Hygiene Day, 28 May 2020
200

150

50

100
Parlez en n'ayez pas honte c'est naturel et n'en faites pas un sujet tabou.

Que les hommes savent qu'en vrai on ne simule pas une douleur mais que nos utérus aiment jouer avec nous.

Les règles ne sont pas sales, $c^{\prime}$ est ce que vous en faites qui peut l'être.

\#MenstrualHygieneDay2020

1:22 PM . 28 mai 2020

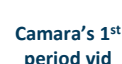

period vid

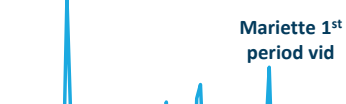

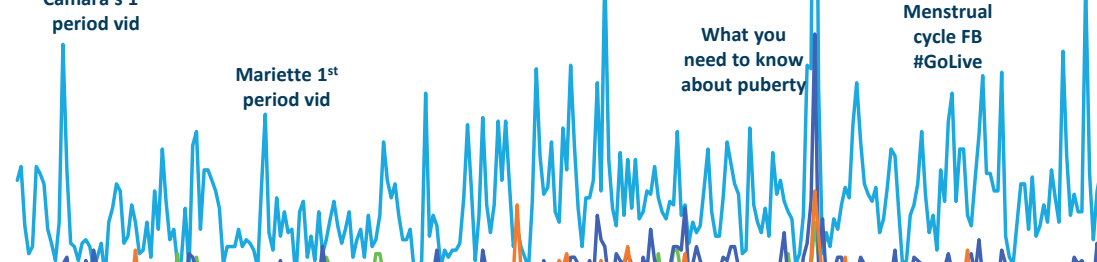

$\mathrm{MMH}$ menstruation/puberty content publication dates are included for reference (grey

annotations).

Spikes aligning with content are not necessarily driven directly by campaign content.

However, in some instances, correlations suggest that content may have contributed to an uptick in regular conversation.

\section{MMH content}

Non-MMH content

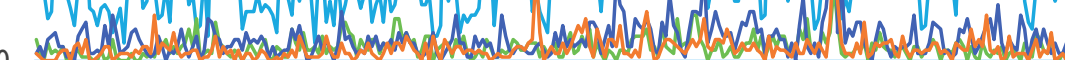
$1 / 1 / 19 \quad 12 / 1 / 19$
$1 / 1 / 2$
$4 / 1 / 20 \quad 5 / 1 / 20$
$6 / 1 / 20$
$7 / 1 / 20$
$8 / 1 / 20$
$9 / 1 / 20 \quad 10 / 1 / 20$
ogo

Niger 


\section{Proportion of replies increases, reflecting more dialogue}

\section{Topline overview (I Nov 20 I9-3 I Jan 202 I)}

Posts on social media can be classified into one of three types: original posts, retweets, or replies.

- An "original post" is a social media post published by an individual/author.

- A "retweet" is when one user shares another person's social post.

- A "reply" is a social media post published in direct response to another author's original post.

In the baseline report, $21 \%$ of menstruation/puberty posts were original posts. While this was more than the $19 \%$ seen across the broader
$\mathrm{RH} / \mathrm{FP}$ conversation, it still signals to how difficult a topic this is for people to discuss openly, due to the sensitive nature of the conversation.

Further, with replies accounting for less than I in $10(9 \%)$ comments, it was clear that this topic had limited dialogue around it.

During the endline review period, original posts fell to $18 \%$. Encouragingly, the volume of replies grew by more than 5-percentage points to reach $14 \%$, accounting for a higher, although not statistically significant, share of the conversation.

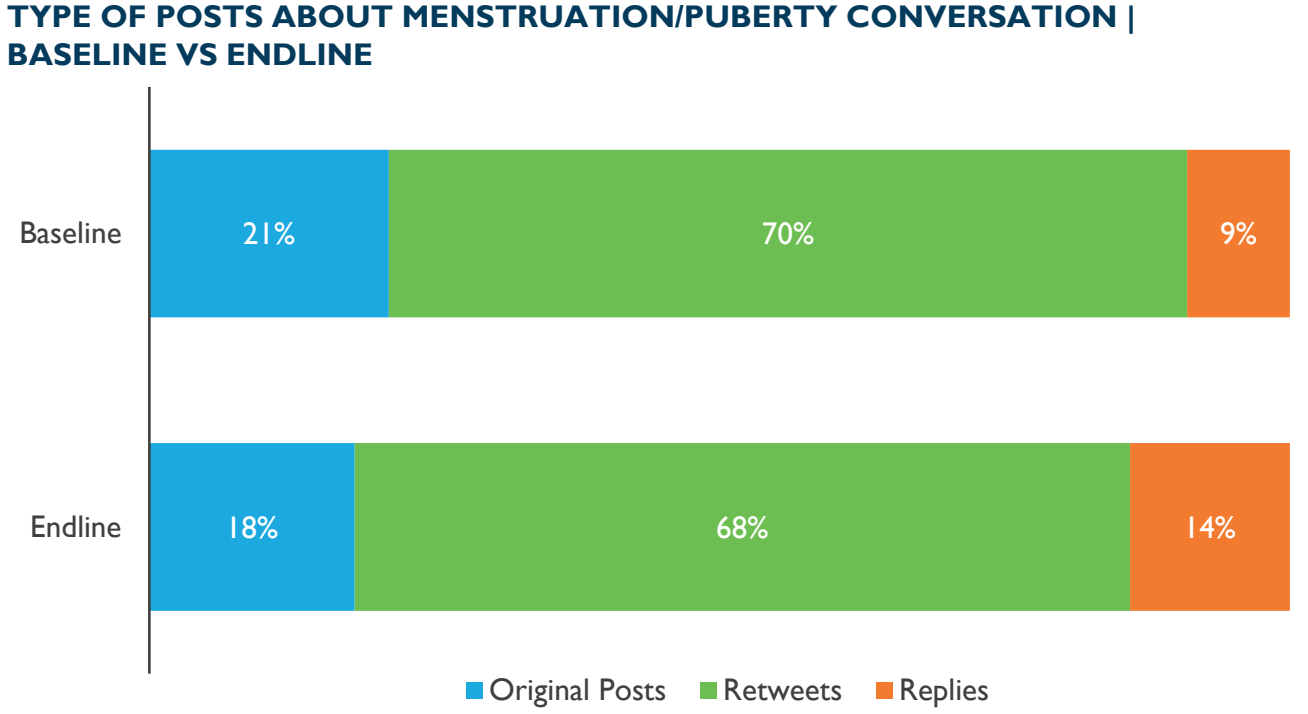




\section{Merci Mon Héros}

\section{Endline Findings}

MMH's presence in menstruation/puberty

conversations | By country 


\section{Mentions of MMH most prominent in Togo}

\section{MMH mentions: Endline vs baseline}

Togo had the most direct mentions of the $\mathrm{MMH}$ campaign on public facing social media, with numerous mention spikes throughout the review period.

In March, the MMH campaign was featured on Togo radio station, VictoireFM, as well as the television show La Poz, on Canal 260. Meanwhile, in September,

@DivisionTogo's tweets around World Contraception Day,

mentioning MMH (among others) generated a significant volume of mentions for $\mathrm{MMH}$.

Overall however, direct mentions of the campaign on public facing social media channels was low throughout the review period, indicating that even though the topics discussed in $\mathrm{MMH}$ content grew in volume, direct attribution of this discussion to $\mathrm{MMH}$ content is not possible.
MERCI MON HÉROS DIRECT MENTIONS BY COUNTRY | ACROSS ALL SUB-TOPICS | I NOV 20I9-3I JAN 202 I

300

250

200 Togo. Un autre rdv important à ne pas manquer às partir de 1 1h30 sur la télévision mère. Soyons tous branché. Soyon tous des héros \#mercimonhéros 7:56 AM $\cdot 10$ mars 2020 $\bigcirc 13 \quad \varnothing 6 \quad \mathcal{P}$ Copier le lien du Tweet

50

0

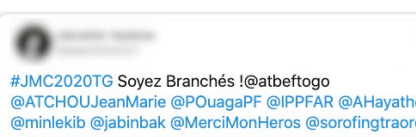
@mintekib @iabinbak @MerciMonHeros @sorofingtraore

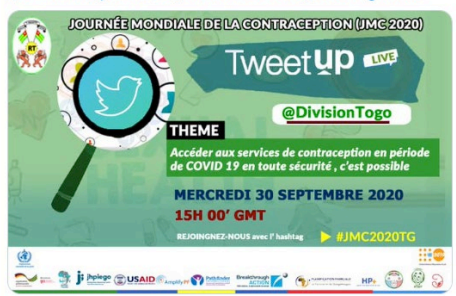
(i)

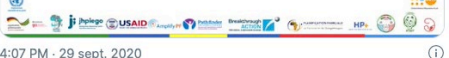
$012 \quad 0>\&$ Copier le lien du Tweet 、 Q C2020TG

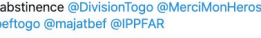

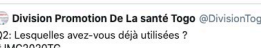

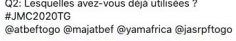
SOURNÉ MONDIALE DE LA CONTRACEPTION UMC C202 (8) L I TWEET UP LIVE Q2 Lesquelles avez-vous déja

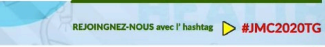

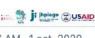

O \& \& Copierle lenen du Tweet

Driven by a tweet by @FatimBlog which reminded people that talking about sex with your child is not encouraging them to have early sex, but preparing them to make wise choices

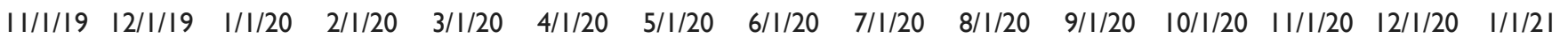




\section{MMH presence in menstruation/puberty sub-topic in each country}

\section{MMH penetration: Endline vs baseline}

The bar chart shows the presence of $\mathrm{MMH}$ mentions in the menstruation/puberty subtopic, across each of the four countries.

While all countries achieved some form of radio and TV broadcast coverage, only Togo shows evidence of significant cross-pollination between mass media and social media, where mass media events were posted about in social media. In Togo, MMH mentions, references, shares, and engagement drove $8.14 \%$ of the menstruation/ puberty conversation.

From this we can extrapolate that increased media coverage correlates to greater presence in sub-topic conversation.

However, the greater share of conversation here is also a reflection of a lower volume of conversation overall.

\section{MERCI MON HÉROS PENETRATION OF CLEANED MENSTRUATION CONVERSATION}

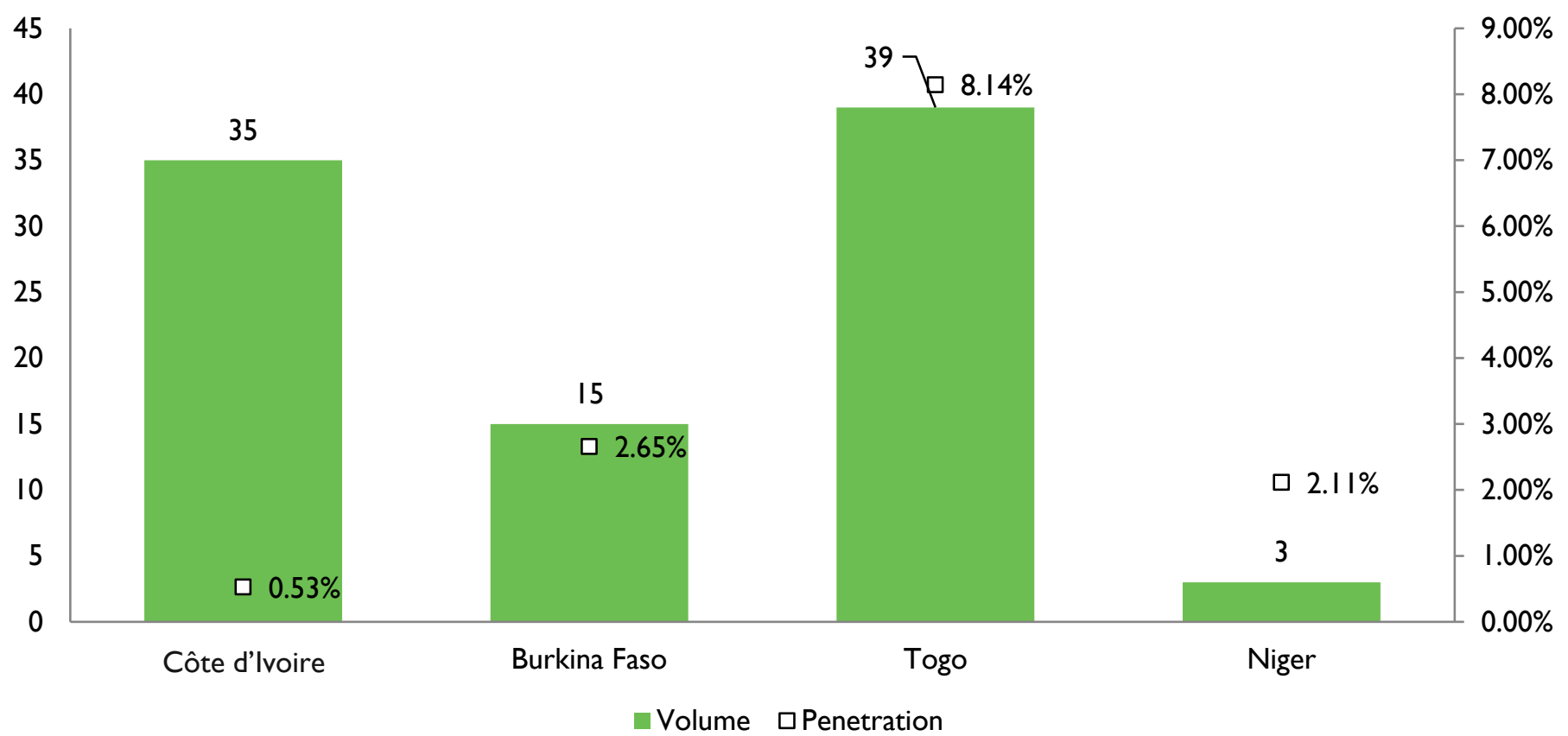

NB. Posts from previous page do not contribute to these figures as they were not menstruation/puberty specific

E.g., this does not include @DivisionTogo tweets.

$9.00 \%$
$8.00 \%$
$7.00 \%$
$6.00 \%$
$5.00 \%$
$4.00 \%$
$3.00 \%$
$2.00 \%$
$1.00 \%$
$0.00 \%$




\section{Côte d'Ivoire}

Menstruation/puberty topic 


\section{Headline stats for Côte d'Ivoire}

- There were $4.2 \mathrm{k}+$ relevant menstruation/puberty topic posts during the 12-month baseline review period. This grew to $6.6 \mathrm{k}+$ relevant posts during the I4-month endline review period.

- The average weekly volume of relevant menstruation/puberty topic posts in Côte d'lvoire grew from 78 during baseline to reach 101 during endline.

- In Côte d'Ivoire, there is a discernable and statistically significant uptick $(p=0.039)$ in conversation volume following publication of $\mathrm{MMH}$ menstruation/puberty content.

- The menstruation/puberty sub-topic accounted for $21 \%$ of total Côte d'Ivoire RH/FP social conversation during the endline review period, up from $13 \%$ in the baseline review.

- The Côte d'Ivoire analysis reveals a significant increase in post replies as a proportion of total comments. This suggests an increased willingness among the online population to engage in conversation relating to menstruation/puberty. This correlates with the publication of $\mathrm{MMH}$ content, with increased volume of comments aligning with content release dates
- The endline report reveals the theme of first periods to have grown to account for $13 \%$ of the menstruation/puberty conversation (up from $6 \%)$. This represents a statistically significant increase $(p=0.021)$. This is driven by an increased number of replies seen in-country during the review period, with far more engagement happening around posts. This increased willingness to engage with the sub-topic, coupled with a statistically significant increase in conversations relating to first periods (a core focus of MMH content), suggests a correlational relationship between the Côte d'Ivoire conversation and the MMH campaign content.

- $27 \%$ of posts refer to the pain associated with periods - up from $23 \%$ during the baseline review. Given the significant emphasis on pain in the dialogue around menstruation/puberty, this offers an obvious route for $\mathrm{MMH}$ to further enhance engagement by producing content that reflects this experience and encourages adults to support adolescents in seeking medical care for their symptoms.

- Mentions of dad alongside period increased by $43 \%$ during the endline review period. This statistically significant increase $(p=0.015)$ in focus on the role of the father was driven by women sharing experiences of their fathers buying them sanitary products, a theme consistent with the baseline review. Given this increasing focus on dads in the conversation, content addressing the role of dads in a daughter's menstruation experience could resonate and drive further engagement. 


\section{Menstruation/puberty overview}

\section{Timeline: endline vs baseline}

The menstruation/puberty subtopic accounted for $21 \%$ of total Côte d'Ivoire RH/FP social conversation during the endline review period, up from $13 \%$ in the baseline review.

The conversation peaked in Côte d'Ivoire on Menstrual Hygiene Day (28 May 2020) with organisations and individuals alike sharing posts to mark the occasion.

The other most notable peak in Côte d'Ivoire conversation was attributable to International Women's Day (8 March 2020) with this event driving conversation around the topic.

MMH should pinpoint events in the calendar which can be used as launchpads for greater exposure.

\section{MENSTRUATION/PUBERTY MENTIONS IN CÔTE D'IVOIRE | I NOV 20 I9-3 I JAN 202 |}

450

400

\section{0}

200

I50 Camara's |st

100 period vid

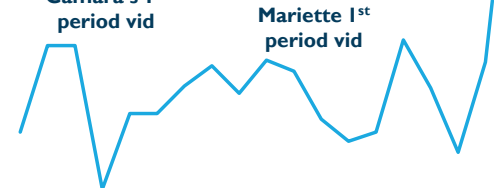

50
Menstrual Hygiene Day, 28 May 2020

International Women's Day, 8 March 2020

0

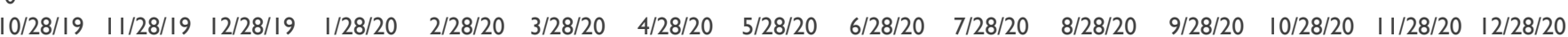

Puberty in

young boy

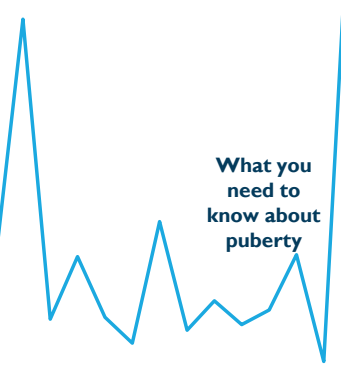

In Côte d'lvoire, overall, there is a discernable and statistically significant uptick $(\mathrm{p}=0.039)$ in

conversation volume during the weeks following

publication of MMH menstruation/puberty content.

\section{MMH content}

Non-MMH content 


\section{Menstruation Google Trends search data}

\section{Search data vs MMH content publication}

Search data specific to menstruation in the Côte d'Ivoire indicates a correlation between some of the MMH content and broader search behavior. However, search behavior also surges

independent of $\mathrm{MMH}$ content.

As such, direct causation cannot be attributed.

However, it is apparent that spikes in search activity around menstruation occurred during weeks in which $\mathrm{MMH}$ published related content. This was true for $4 / 5$ of the $M M H$

menstruation/puberty posts, as shown.

Spikes also coincided with other important events in the calendar such as International Women's Day and Menstrual Hygiene Day.

\section{MENSTRUATION SEARCH DATA | CÔTE D'IVOIRE | I NOV 20 I9-3 I JAN 202 I}

100

90

80

70

60

50

40

40

30

20

10

0

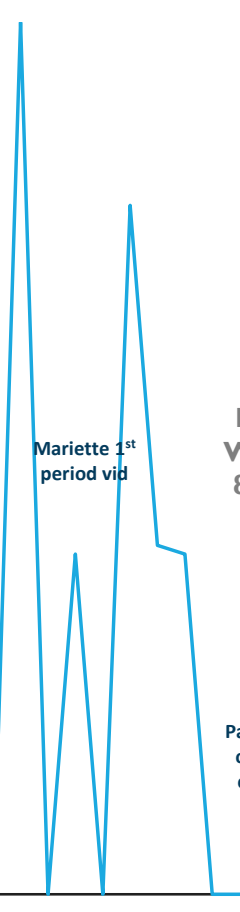
Women's Day, 8 March 2020

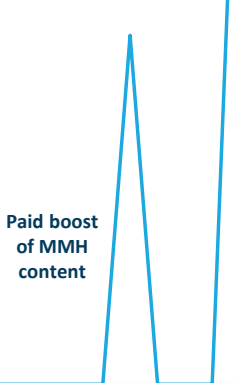

$3 / 3 / 20$
International

Menstrual

Hygiene Day, 28 May 2020

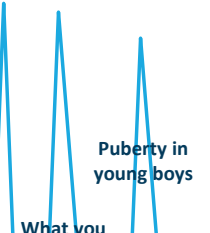
bout puberty \#Golive

$\begin{array}{llll}01 / 3 / 19 & 12 / 3 / 19 & 1 / 3 / 20 & 2 / 3 / 20\end{array}$
Google Trends search data shows how frequently a given term is searched for relative to total search volume for a country, over a period of time.

A value of 100 is the peak popularity of the term, whilst a value of 0 means that the term did not

register at all during that week, relative to other online searches in the country.

\section{MMH content}

Non-MMH content

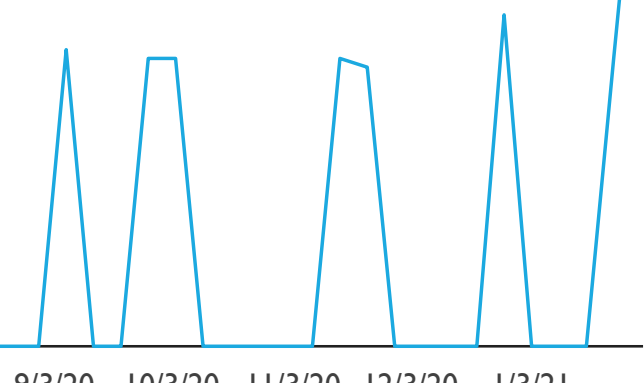




\section{Focus on first periods (a key MMH theme), increases $2 x$ in size}

\section{First period: endline vs baseline}

The baseline report revealed a common theme in the discussion around menstruation/puberty, with $6 \%$ of posts relating to the experience of the first period. The endline report reveals this theme to have grown considerably to reach $13 \%$.

This is driven by an increased number of replies seen incountry during the review period, with far more

engagement happening around posts.

This increased willingness to engage with the sub-topic, coupled with a statistically significant increase $(p=0.021)$ in conversations relating to first periods (a core focus of $\mathrm{MMH}$ content), suggests a correlational relationship between the Côte d'Ivoire conversation and the $\mathrm{MMH}$ campaign content.

\section{FIRST PERIOD MENTIONS AS A PROPORTION OF MENSTRUATION/PUBERTY MENTIONS | CÔTE D'IVOIRE | BASELINE VS ENDLINE}

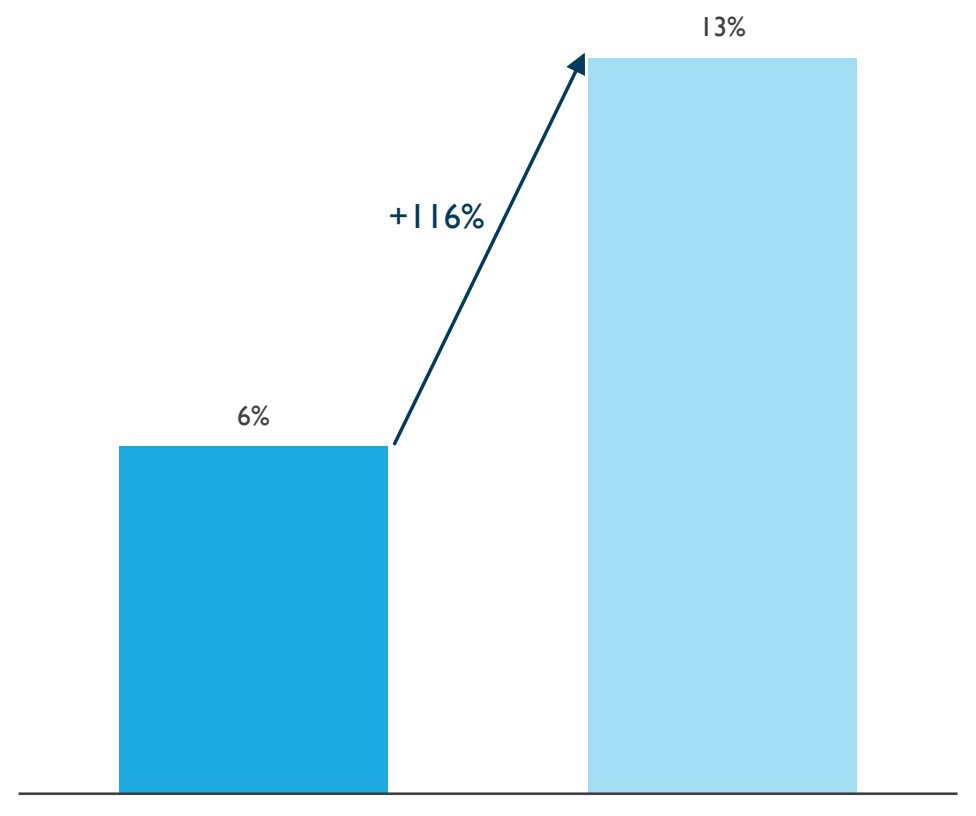

Baseline
Moi le jour de mes premières règles j'étais à l'internat les filles ont fait une collecte de serviettes hygiéniques pour moi elles se sont misent à danser en disant Jsuis devenue femme mdr

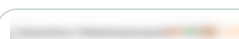

Je me souviens quand maman me donnait Lilas pour mes premières règles

L'enfant marchait comme canard dans Abidjan, le bail c'était 作

(

$$
\text { ○ } 4
$$$$
\uparrow
$$

\#suisuntemoin

\#TopFilles

Préparons nos fillettes à la découverte de leurs premières \#menstrues afin d'éviter 1autre forme de violence qui ne dit pas son nom et n'a pas sa raison d'être.

Brisons le tabou ds règles à nos filles.

\#education \#JeVeuxSavoir @Equipop_Ong

4:47 AM - 24 janv. 2021 depuis Côte d'Ivoire 


\section{An example of the dialogue around first period experiences}

\section{First period: Endline vs baseline}

Evidence of the increasing engagement in dialogue around first period experiences is shown, with one user, "...convinced that the speech that a young girl hears when she has her first period is important because it conditions her perception of menstruation and the changes it will experience."

This user asks followers to share the words they heard on the day they had their first period.

Responses were predominantly made private, though some posts remained availablemainly those showing support for the initiative, further showcasing a a growing acceptance and championing of these types of conversations incountry.

\section{STARTING THE DIALOGUE AROUND FIRST PERIOD EXPERIENCES AND THE ADVICE RECEIVED |} CÔTE D'IVOIRE | 24 JANUARY 2020

Je Lance le \#JeSuisReglée !

Dans le cadre de mon \#ProjetSocial2020, j'ai choisi de m'intéresser à la précarité menstruelle. Je suis convaincue que le discours que la jeune fille entend lorsqu'elle a ses premières règles est important, surtout parce que celui-ci conditionne sa
Q 5
七】 34
○ 27
个

perception de la menstruation et des changements qu'elle va vivre. Quels mots as-tu entendu, le jour où tu as eu tes premières règles ? Quels mots aurais-tu aimé entendre?

Tous vos témoignages feront l'objet d'un recueil qui sera diffusé, ceci tout en veillant à ce que les
Q 1
〔】 8
O 3
个
7:25 AM - Sep 1, 2020 - Twitter for Android

Replying to @tinetteyouan

Super. J'aime beaucoup l'initiative. Bravo Translate Tweet

8:31 AM - Mar 8, 2020 - Twitter for Android

Replying to @tinetteyouan

J'aime. Belle initiative

Translate Tweet informations nécessaires à une menstruation épanouie soient transmises.

On se lance ?

\#JesuisRéglée \#PrécaritéMenstruelle

Q

〔】 5

O 4

$\uparrow$ 


\section{Pain dialogue grows in size During review period}

\section{Pain: Endline vs baseline}

The baseline report revealed a common theme in the discussion around menstruation/puberty, with $23 \%$ of posts relating to the pain associated with periods. The endline report reveals this theme to have grown to reach $27 \%$.

The analysis reveals a consistent volume of posts referencing pain, highlighting that this is a dominant theme within the broader conversation.

Given the significant emphasis on pain in the dialogue around menstruation/puberty, this offers an obvious route for $\mathrm{MMH}$ to further enhance engagement by producing content that addresses pain.

MMH should consider tailoring messages and videos that encourage adults to support adolescents in managing their period pain and seeking medical care for their symptoms if needed.

\section{PAIN MENTIONS AS A PROPORTION OF MENSTRUATION/PUBERTY MENTIONS | CÔTE D'IVOIRE | BASELINE VS ENDLINE}

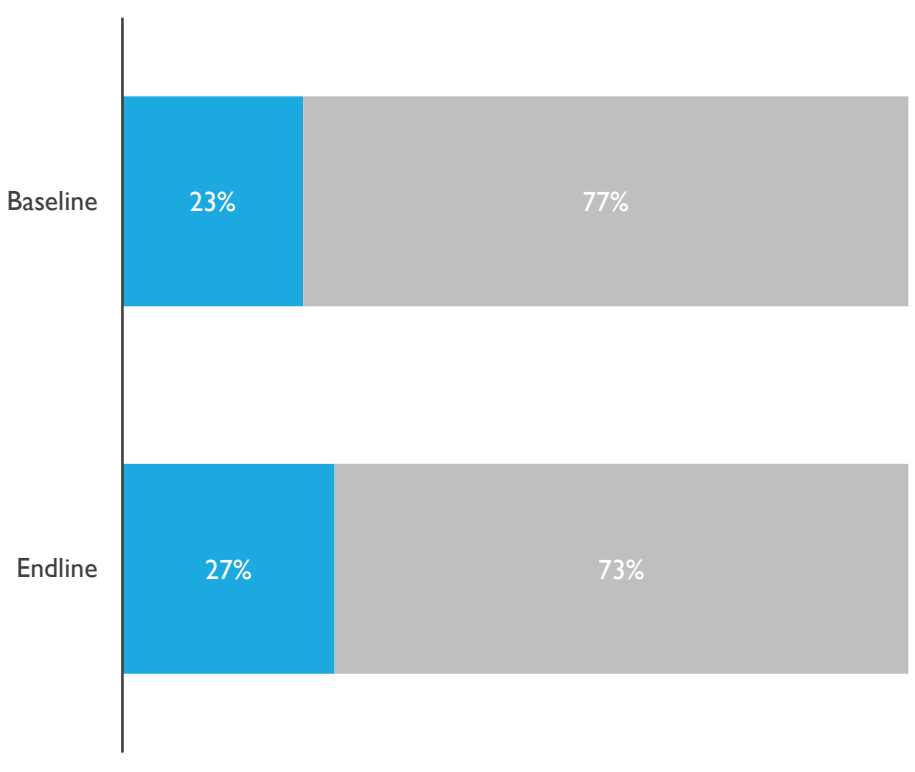

Pouah je déteste être en période de menstruation pffff .. tout mon corps me fait mal $=$

1:41 AM $\cdot 20$ nov. 2020

$\bigcirc \vee \mathcal{Q}$ Copier le lien du Tweet

J'ai vraiment du mal à travailler les quelques jours avant mes règles. C'est affreux

1:40 PM $\cdot 9$ nov. 2020

$\bigcirc 3 \bigcirc \odot$ Copier le lien du Tweet

Je me demande ce que j'ai fais à Dieu pour mériter des règles aussi douloureuses

9:36 AM $\cdot 3$ janv. 2021 


\section{Notable increase in replies shows growth in engagement}

\section{Starting conversations: Endline vs baseline}

The Côte d'Ivoire analysis reveals a notable increase in post replies as a proportion of total comments. This may suggest an increased willingness among the online population to engage in conversation relating to menstruation/puberty. This correlates with the publication of MMH content, with increased volume of comments aligning with content release dates.

The analysis reveals discussion happening around pain medication advice (both medicinal and just personal habits), educational conversations answering questions around the topic and posts encouraging people to continue to talk about the topic to remove any taboo.
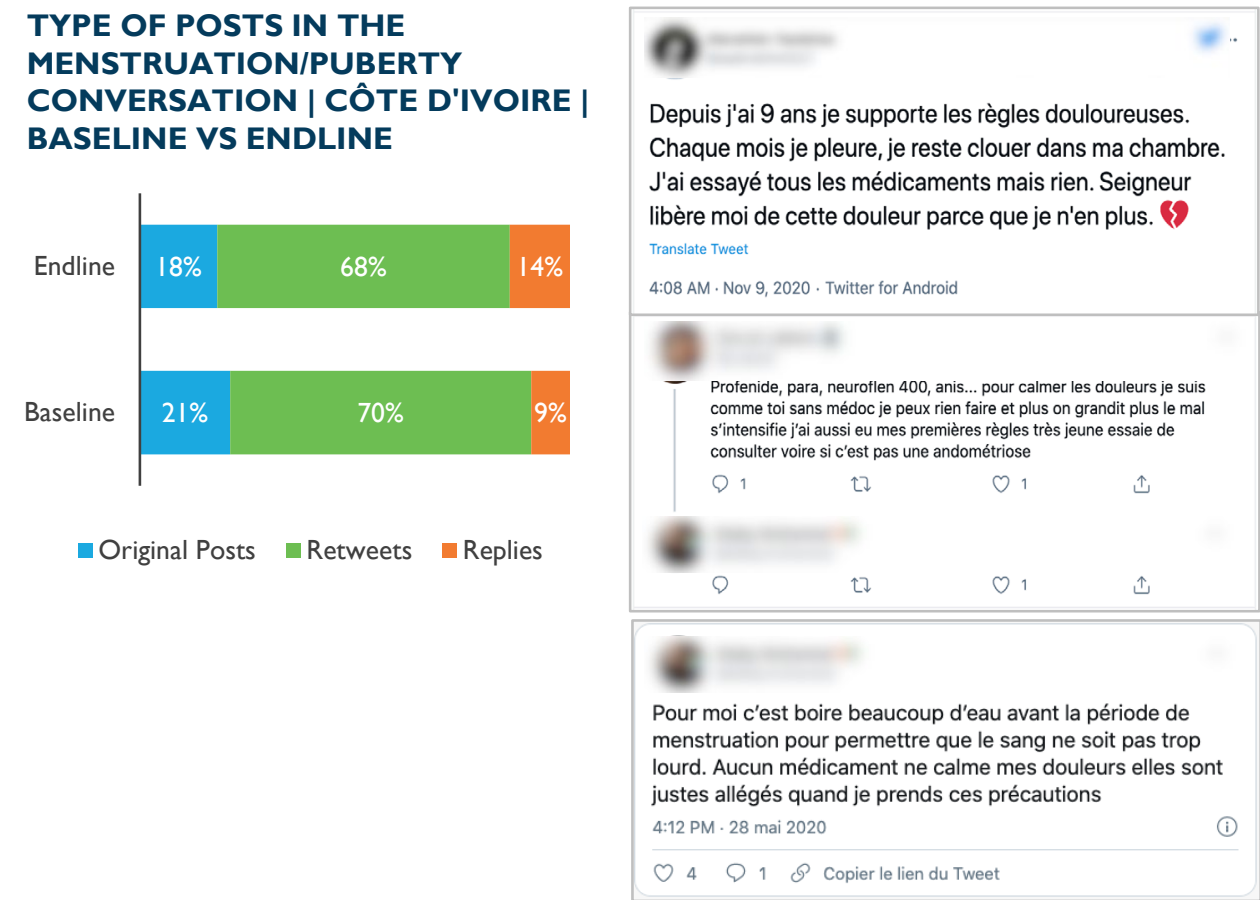

Pour moi c'est boire beaucoup d'eau avant la période de menstruation pour permettre que le sang ne soit pas trop justes allégés quand je prends ces précautions $\mathcal{O}_{4} \bigcirc 1 \mathcal{S}$ Copier le lien du Tweet
Moi je pensais que les filles arrivé à un certain âge ont leurs menstrues jusqu'à la ménopause

Oui oui c'est exact mais elles n'ont pas toutes des règles douloureuses

3:06 PM 3 déc. 2020

$\bigcirc \bigcirc \mathcal{G}$ Copier le lien du Tweet

Merci A. Moi j'ai essayé tellement de comprimés et méthodes mais quand je fais 1 mois ou 2, le mois suivant le médoc n'a plus la même efficacité contre la douleur.

Ah ça Je suis dépassée par le phénomène même! C'est ici

j'ai su que ce qu'on appelle règles DOULOUREUSES.

II m'arrive souvent de me tordre de douleur, mais là c'est pend6abr la 1ère nuit quand je suis éveillée. Le matin ça passe (paracétamol gère mon mal proooopre la nuit)

6:01 PM - 28 mai 2020

$\bigcirc 1 Q 1 \mathcal{O}$ Copier le lien du Tweet 


\section{Mention of dad alongside period increases by $43 \%$}

\section{Family/support: Endline vs baseline}

The baseline report revealed that mothers were the most prominent support network member mentioned alongside periods, accounting for $31 \%$ of relevant mentions. This remained consistent during the endline review.

There was a statistically significant increase $(p=0.015)$ on the role of the father $(+6 \%)$, in the conversation during the endline review.

Several users shared experiences of their fathers buying them sanitary products, a theme consistent with the baseline review.

Given this increased focus on dads in the conversation, content addressing the role of dads in a daughter's menstruation experience could resonate and drive engagement.
SUPPORT NETWORK MENTIONS ALONGSIDE PERIOD DISCUSSIONS | CÔTE D'IVOIRE | BASELINE VS ENDLINE

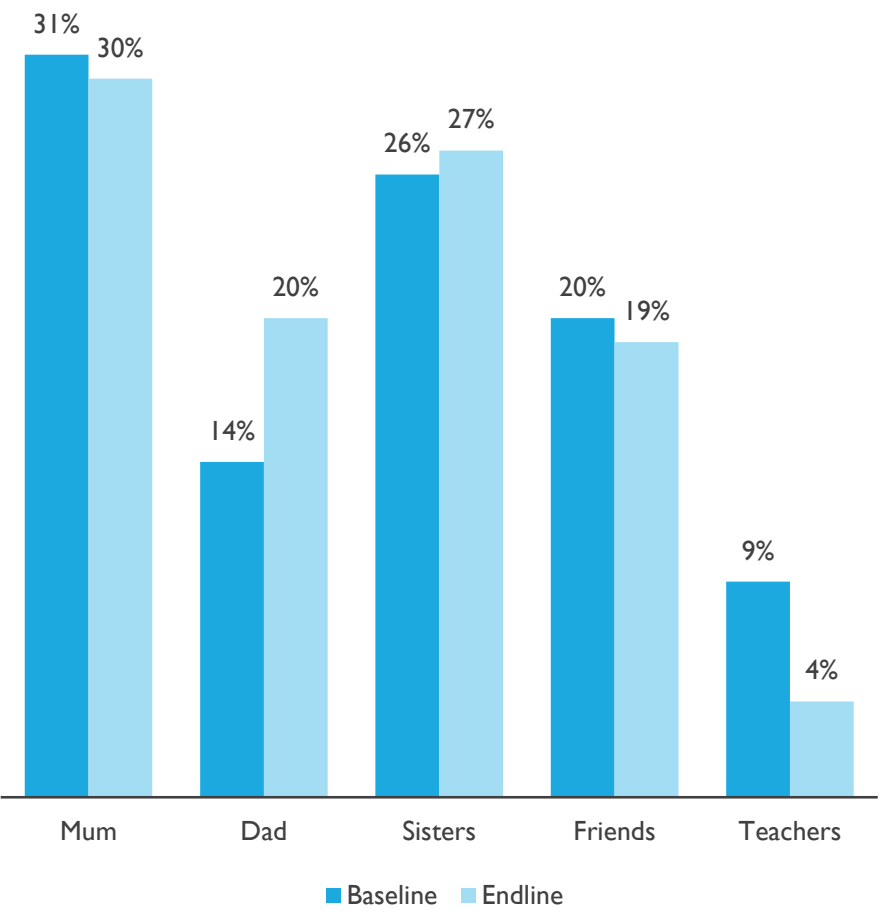

Même si on s'tape vite dessus je remercie Dieu d'avoir eu un père qui n'a que peu de tabous (dans la limite du raisonnable les gars). Bien heureuse aussi d'avoir un père limite trop ouvert sur le sujet des règles, et compréhensif de cette douleur

8:08 PM - 31 mai 2020

$\bigcirc \odot \odot$ Copier le lien du Tweet

\#jesuisreglée depuis les 12ans. J'ai appelé ma soeur et elle a informé papa. II achetait maintenant les serviettes périodiques en gros. Si ça ne me convenait pas il allait chercher un nouveau modèle.

On n'a jamais parlé de la suite des règles. Je savais déjà tout vu que je me

4:56 PM - 8 mars 2020 


\section{Burkina Faso}

Menstruation/puberty topic 


\section{Headline stats for Burkina Faso}

- There were $300+$ relevant menstruation/puberty topic posts during the 12month baseline review period. This grew to 565 relevant posts during the 14-month endline review period.

- The average weekly volume of relevant menstruation/puberty topic posts in Burkina Faso grew from six during baseline to nine during endline.

- In Burkina Faso, there is no discernable/statistical uptick in conversation volume following publication of MMH menstruation/puberty content.

- The menstruation/puberty sub-topic accounted for 19\% of total Burkina Faso RH/FP social conversation during the endline review period, up from $13 \%$ in the baseline review. However, in Burkina Faso, this increased share of voice is driven by other sub-topics shrinking, rather than a notable increase in interest.

- Aside from Menstrual Hygiene Day, there were no significant peaks in conversation. The Burkina Faso analysis reveals the majority of posts in this sub-topic were driven by shares/retweets of content, demonstrating a reluctance for open dialogue around the topic in-country.

- However, the share of replies in the conversation doubled during the endline review (albeit, from just 1\% to $2 \%$ ), indicating a positive direction for increasing engagement.
- Baseline analysis revealed I3\% of Burkina Faso posts were tied to the experience of first periods. The endline analysis reveals this theme to have grown to $19 \%$. While some posts achieve a degree of engagement, the majority garner few comments/retweets, demonstrating a reluctance for open dialogue around the topic.

- The increased share of first period specific posts points to a possible correlation between MMH content themes and Burkina Faso conversation. However, it should be noted that this growth has been driven predominantly by organisations/initiatives (other than $\mathrm{MMH}$-e.g., Unicef) trying to raise awareness of (and engagement with) the conversation.

- Pain associated with menstruation accounted for $28 \%$ of sub-topic mentions, up from 17\% during the baseline review period. Given the significant emphasis on pain in the dialogue around menstruation/puberty, this offers an obvious route for $\mathrm{MMH}$ to further enhance engagement by producing content that acknowledges this experience and encourages the audience to consult a healthcare professional.

- Mentions of sisters increased by $4 \%$, reflecting a slightly greater emphasis placed on the role of sisters in the menstruation conversation during the endline review. This refers to both familial sisters, as well as the sense of female sisterhood. This increased emphasis on the role of sisters/sisterhood in the menstruation conversation offers an opportunity for $\mathrm{MMH}$. Future content should leverage this by championing the role of sisters/sisterhood in learning about menstruation. 


\section{Menstruation/puberty overview}

\section{Burkina Faso timeline: Endline vs baseline}

The menstruation/puberty subtopic accounted for $19 \%$ of total Burkina Faso RH/FP social conversation during the endline review period, up from $13 \%$ at baseline.

However, in Burkina Faso, this increased share of voice is driven by other sub-topics shrinking, rather than a tangible increase of interest in this sub-topic.

The conversation peaked on World Menstrual Hygiene Day (28 May 2020) with organisations and individuals alike sharing posts to mark the occasion.

There were no other significant peaks in conversation, with extremely limited engagement (shares, comments, retweets) around the topic during the review period.

\section{FIRST PERIOD MENTIONS AS A PROPORTION OF MENSTRUATION/PUBERTY MENTIONS | BURKINA FASO |} BASELINE VS ENDLINE

0
Menstrual Hygiene Day, 28 May 2020

\section{MMH content}

Non-MMH content
In Burkina Faso, there is no discernable/statistical uptick in conversation volume following publication of MMH menstruation/puberty content.

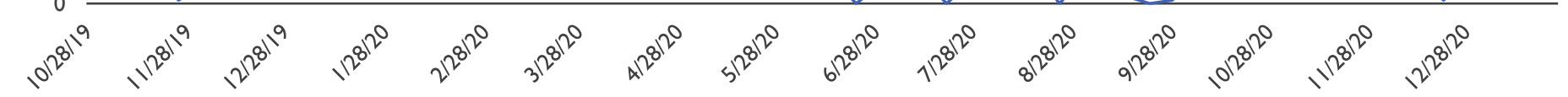




\section{Menstruation Google Trends search data}

\section{Search data vs MMH content publication}

Search data specific to menstruation in Burkina Faso loosely correlates with MMH topic content, indicating a potential correlation between $\mathrm{MMH}$ content and broader search behavior.

However, direct causation cannot be attributed.

Three of the seven spikes in search activity around

menstruation occurred during weeks in which MMH published related content. This was true for 3/5 of the MMH menstruation/ puberty posts, as shown.

Notably, the paid boost of MMH content in late March coincided with a significant search spike, though this could also have been driven by International Women's Day (8 March 2020) among other things.

\section{MENSTRUATION SEARCH DATA | BURKINA FASO | I NOV 20 I9-3 I JAN 202 I}

100

90

70

60

50

40

30

20

10 period vid

0

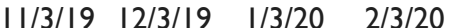

International

Women's Day,

8 March 2020

Paid boost of MMH content

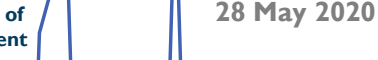

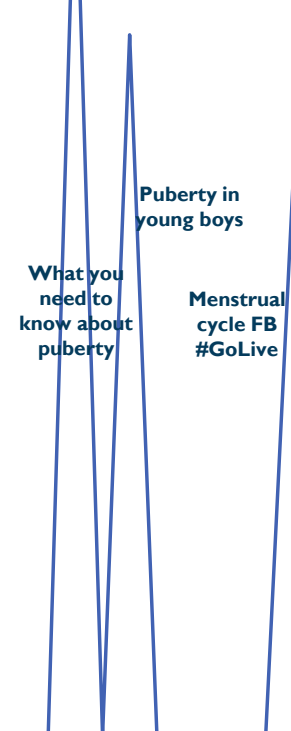

Google Trends search data shows how frequently a given term is searched for relative to total search volume for a country, over a period of time.

A value of 100 is the peak popularity of the term, whilst a value of 0 means that the term did not register at all during that week, relative to other online searches in the country.

MMH content

Non-MMH content 


\section{Focus on first periods (a key MMH theme) increases by $46 \%$}

\section{First period: Endline vs baseline}

The baseline report revealed $13 \%$ of Burkina Faso posts were tied to the experience of first periods. The endline report shows this theme increased to $19 \%$.

This is driven predominantly by organisations/initiatives trying to raise awareness of (and engagement with) the conversation.

While some posts achieved limited engagement, the majority garner few comments/retweets, demonstrating a reluctance for open dialogue around the topic.

However, the increased share of first period specific posts points to a correlation between MMH content themes and Burkina Faso conversation, indicating a degree of potential resonance.
FIRST PERIOD MENTIONS AS A PROPORTION OF MENSTRUATION/PUBERTY MENTIONS | BURKINA FASO | BASELINE VS ENDLINE

$19 \%$

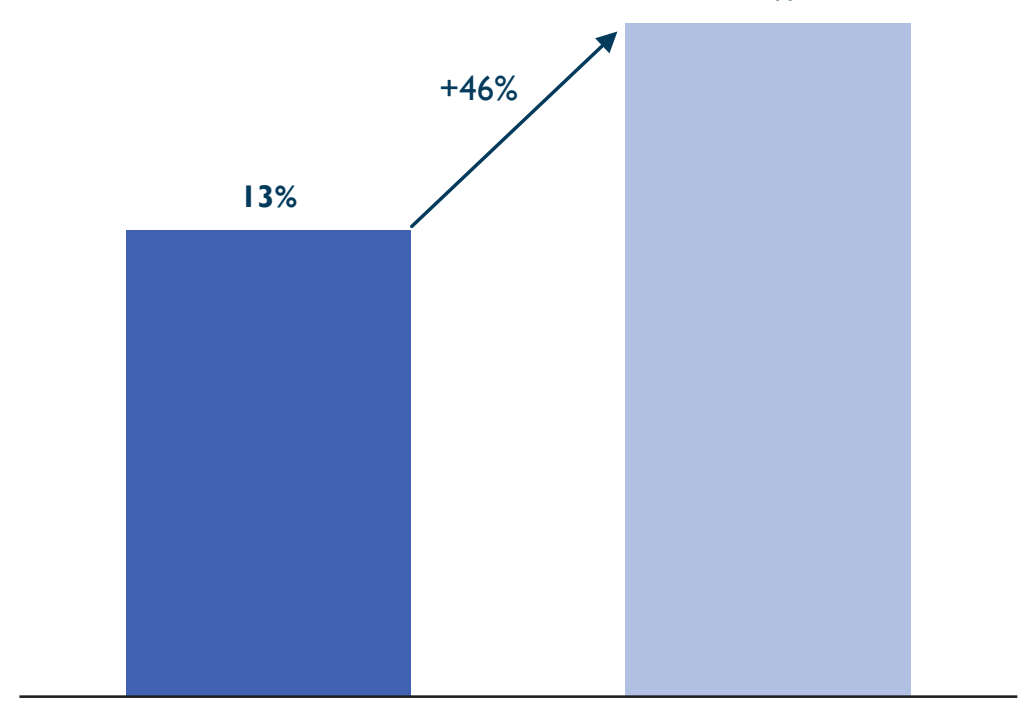

BASELINE
Aminata a été donnée en mariage dès l'apparition de ses premières règles.

Cliquez sur le lien pour découvrir son histoire. Abonne toi et offre un vote à son histoire "règles douloureuses"

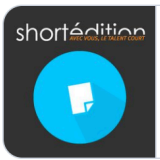

Règles douloureuses

Suis-je dans le noir ou ai-je les yeux fermés ? Peut-

être les deux. Peu importe, cela n'a plus d'importance.

os short-edition.com

6:00 AM $\cdot 8$ mai 2020

○ $3 \quad Q 4 \quad \mathcal{S}$ Copier le lien du Tweet

J'ai eu mes premières règles a 9 ans et la personne qui s'est chargée de tout m'expliquer c'était ...mon papa été magnifique avec ses conseils et jusqu'à sa mort il vérifiait toujours que j'avais mes serviettes.

\#MenstrualHygieneDay

9:37 AM · 28 mai 2020 


\section{Limited dialogue around first period experiences}

\section{First period: Endline vs baseline}

While dialogue in response to comments was low in Burkina Faso, it was not entirely absent.

A limited number of posts from organisations/initiatives sparked a degree of conversation.

For example, post from @BilliNowNowll generated some discussion, with one parent commenting that "First menstruation must be the occasion for intimate parentdaughter contact. A first experience...under empathetic parenting."

MMH may consider leveraging partnerships with campaigns such as@BilliNowNowll in

28 Mai: Journée mondiale consacrée à l'hygiène menstruelle.

En Afrique, 66\% des filles ne disposent pas d'une bonne information sur la menstruation avant d'être confrontées à leurs premières règles

\#MenstrualHygieneDay2020 \#Billi4GHM

\#Billi4EndStigma

\#BilliNowNowll \#BNNII \#Santé Translate Tweet

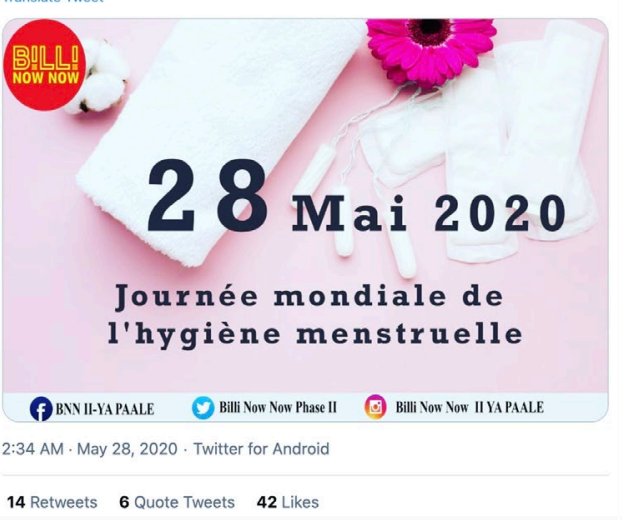

Pourtant les menarches(7eres règles)dolvent ëtre l'occasıon d'un contact intime parent-fille; une première expérience pour la fille de pratiquer les conseils relatifs à une bonne gestion de l'hygiène menstruelle; sous évaluation empathique du parent! @POuagaPF

@ippf

ใ】 1

03

$\uparrow$

Ensemble, brisons les tabous. II est important que Ça se sache. Les menstruations sont une partie de la vie des jeunes femmes.\#Billinownowl

$\uparrow\urcorner$

O 1

$\uparrow$

II faut brisé le Tabou pour le bien être de jeune sœur

七】

03

$\uparrow$

C'est un droit pour la jeune fille, nous devons les soutenir en les donnant l'information approprié.

\#MenstrualHygieneDay2020 \#Billi4GHM

\#BilliNowNow \#BNNII \#Santé

$\varnothing$
02 


\section{Pain dialogue grows in size during review period}

\section{Pain: Endline vs baseline}

The baseline report revealed $17 \%$ of Burkina Faso posts were tied to the experience of pain. The endline report shows that this theme increased to $28 \%$.

As is evident throughout the analysis in all countries, the pain experienced during periods is a dominant theme.

Given the significant emphasis on pain in the dialogue around menstruation/puberty, this offers an obvious route for $\mathrm{MMH}$ to further enhance engagement by producing content that addresses this shared experience.

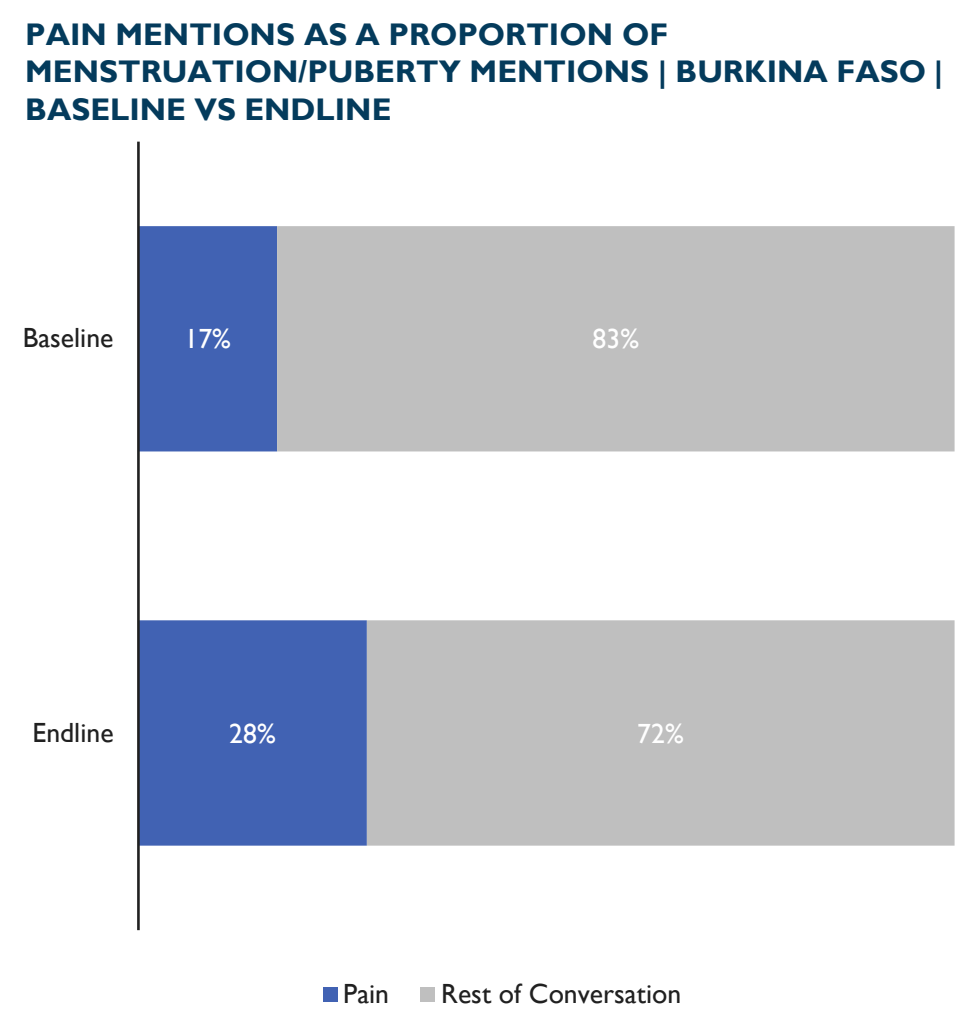

On paye quoi avec les règles douloureuses ... Seigneur c'est comme si on prend le couteau on ouvre ton bas du dos, ton bas ventre ... Puis la fièvre s'ajoute dessus et les maux de têtes ... C'est horrible \%

3:48 PM . 28 janv. 2021

○ $5 \odot \odot$ Copier le lien du Tweet

S'il y avait la possibilité de supprimer quelque chose dans ce monde, je supprimerais les règles douloureuses 6:54 AM - 12 janv. 2021

$$
\mathcal{P} \text { Copier le lien du Tweet }
$$

Je dis vraiment Alhamdoullilah mes règles sont plus douloureuses du tout evant c̀ cause de lo douleur je pleurais je passis toute la journé dans chambre je mangeais pas mais au fil du temps ça a diminué et la vraim la je ressens presque rien souvent juste des petits maux mais Q 2 セ】 1 ○ 6 个

Franchement c'est rien comparé à la douleur d'avant Q o $\uparrow$ 


\section{Burkina Faso replies extremely limited (but $2 x$ growth)}

\section{Starting conversations: Endline vs baseline}

The Burkina Faso analysis reveals the majority of posts in this sub-topic are driven by shares/retweets of content, demonstrating a reluctance for open dialogue around the topic in-country.

However, the share of replies in the conversation doubled during the endline review (albeit, from just $1 \%$ to $2 \%$ ), indicating a positive direction for increasing engagement.

Further, there is some evidence of inter-generational conversations happening, as shown here by a man replying to a young girl's tweet, sharing his wife's experience of periods after childbirth.
TYPE OF POSTS |

MENSTRUATION/PUBERTY CONVERSATION | BASELINE VS ENDLINE

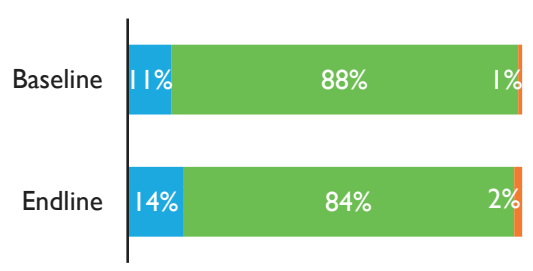

Original Posts $\square$ Retweets $\square$ Replies
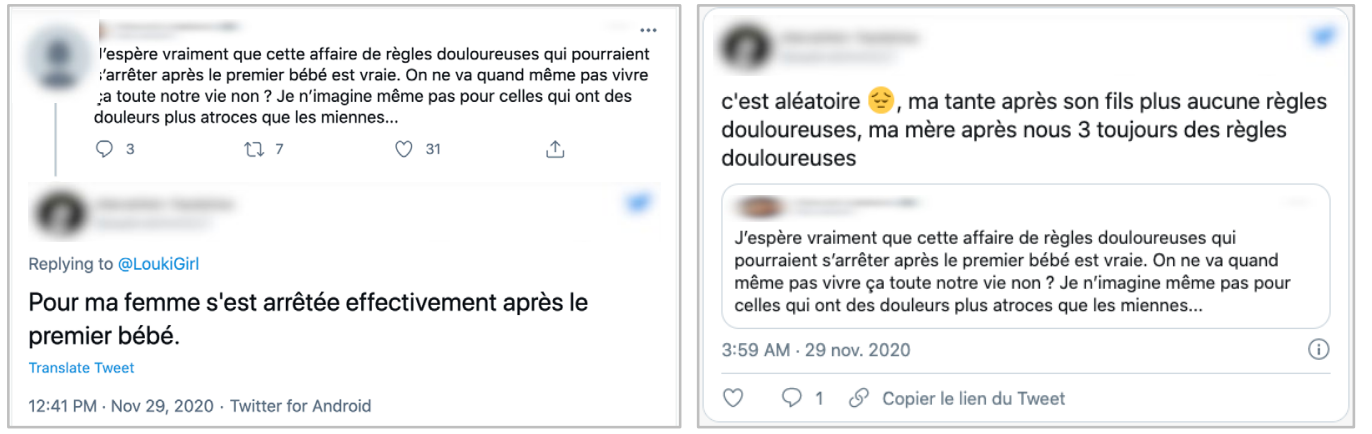

c'est aléatoire $=$, ma tante après son fils plus aucune règle douloureuses, ma mère après nous 3 toujours des règles pourraient s'arrêter après le premier bèbé est vraie. On ne va quand celles qui ont des douleurs plus atroces que les miennes.

$\mathcal{Q} 1 \mathcal{B}$ Copier le lien du Tweet 


\section{Mention of sister alongside period increases by $4 \%$ points}

\section{Starting conversations: Endline vs baseline}

Support members' share of conversation remained largely consistent over review periods, with only slight growth/declines

witnessed.

The baseline report revealed that mothers were the most prominent support network member mentioned alongside periods, accounting for $29 \%$ of relevant mentions. This declined slightly to $26 \%$ during endline.

Meanwhile, sisters grew $+4 \%$, which while not statistically significant, still represented strong growth. Sisters refers to both familial sisters, as well as the sense of female sisterhood.

This increased emphasis on the role of sisters/sisterhood in the menstruation conversation offers an opportunity for MMH. Future content should leverage this by championing the role of

sisters/sisterhood in learning about menstruation.

\section{SUPPORT NETWORK MENTIONS ALONGSIDE PERIOD DISCUSSIONS | BURKINA FASO | BASELINE VS ENDLINE}

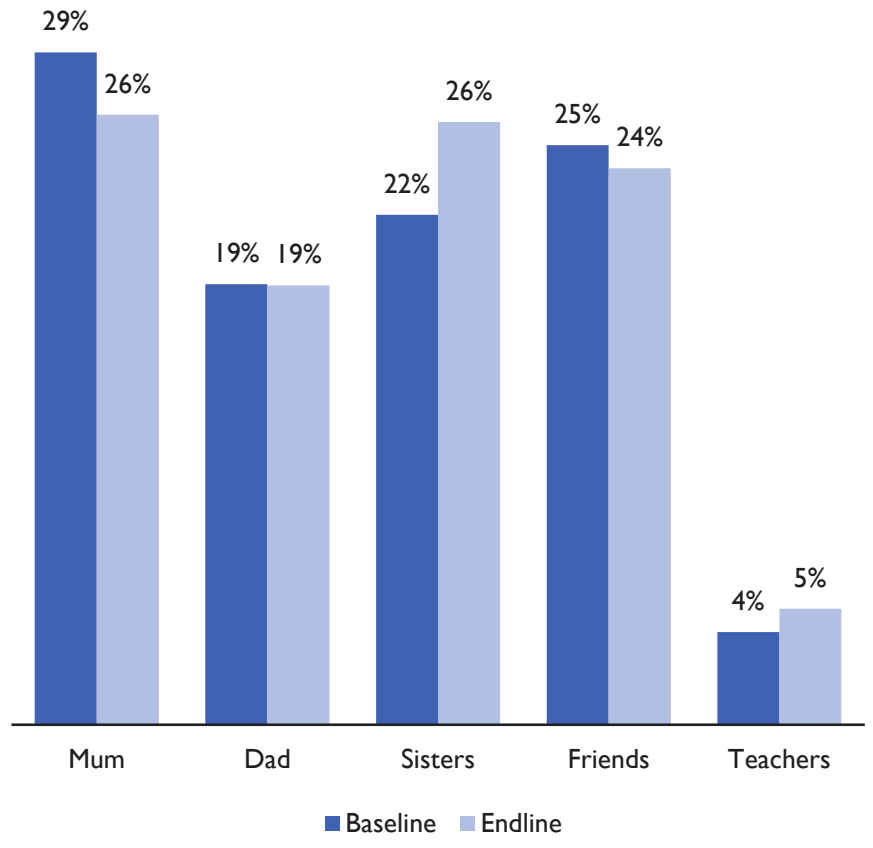

Ma soeur quand elle a ses règles elle est tellement des mauvaises humeurs et elle répond mal t'a l'impression qu'elle a une mitraillette a la place de la bouche

7:23 AM $\cdot 31$ janv. 2021

O $34 \bigcirc 29 \odot$ Copier le lien du Tweet

\section{o}

\#jesuisréglée

Personne ne m'a appris à compter mes jours quand j'ai eu mes règles. Les explications en cours étaient très floues pour moi, je crois que j'ai appris quand j'étais déjà à

l'université avec des grandes sœurs de l'école pour savoir ma période " dangereuse ".

6:04 AM $\cdot 8$ mars 2020 
Togo

Menstruation/puberty topic 


\section{Headline stats for Togo}

- There were 320 relevant menstruation/puberty topic posts during the 12-month baseline review period. This grew to 585 relevant posts during the 14-month endline review period.

- The average weekly volume of relevant menstruation/puberty topic posts in Togo grew from 6 during baseline to reach 10 during endline.

- In Togo, there was a slight uptick in conversation volume directly following publication of MMH menstruation/puberty content.

- The menstruation/puberty sub-topic accounted for $18 \%$ of the total Togolese RH/FP social conversation during endline, up from I3\% during baseline.

- There was also a discernible, statistically significant increase $(p=0.04 I)$ in sub-topic mentions during the week of the MMH panel discussion on menstruation, suggesting a correlational relationship between the Togo menstruation/puberty conversation and the MMH campaign content.

- In Togo, the endline review reveals the theme of first periods to have grown by a massive $+172 \%$ to reach $30 \%$. The analysis shows evidence of people engaging in conversation about their own first period experiences in order to break the taboo around the topic-a goal of the $\mathrm{MMH}$ campaign. This further demonstrates the correlational relationship between the Togo conversation and the MMH campaign content.
- Pain associated with menstruation accounted for $27 \%$ of sub-topic mentions, up from $23 \%$ during the baseline review period. Given the significant emphasis on pain in the dialogue around menstruation/ puberty, this offers an obvious route for $\mathrm{MMH}$ to further enhance engagement by producing content that reflects this experience and encourages the audience to consult a healthcare professional to ensure they are okay.

- The Togo analysis saw significant growth in both original posts and replies, demonstrating a growing appetite for (and acceptance of) dialogue around the topic. The share of replies grew from 2\% to $5 \%$ during the review period, indicating a positive direction for increasing engagement.

- Mentions of sisters as a key support group increased $8 \%$, reflecting a far greater emphasis placed on the role of sisters in the menstruation conversation during the endline review. Future content should leverage this learning by championing the role of sisters in learning about menstruation. 


\section{Menstruation/Puberty Overview}

\section{Togo timeline: Endline vs baseline}

The menstruation/puberty subtopic accounted for $18 \%$ of the total Togolese RH/FP social conversation during the endline review period, up from 13\% during baseline.

As in the Côte d'Ivoire, the conversation peaked on World Menstrual Hygiene Day with a second notable peak driven by International Women's Day.

There was also a discernible, statistically significant $(p=0.04 \mathrm{I})$ increase in first period sub-topic mentions during the week of the $\mathrm{MMH}$ panel discussion on menstruation.

Although some increase in topicspecific conversation may have been driven by International Women's Day, the timing suggests a correlational relationship between the Togo menstruation/ puberty conversation and the $\mathrm{MMH}$ campaign content.

\section{FIRST PERIOD MENTIONS AS A PROPORTION OF MENSTRUATION/PUBERTY MENTIONS | TOGO |}

BASELINE VS ENDLINE

100

90

80

70

60

50

International Women's Day, 8 March 2020

40

30

Camara's Ist $^{\text {st }}$

Camara's

MMH podium show

Internat

10

0$$
\text { period vid }
$$

$10 / 28 / 1$

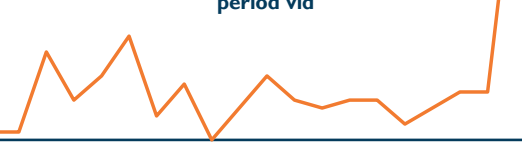

Menstrual Hygiene Day, 28 May 2020

In Togo, there is a slight uptick in conversation volume following publication of $\mathrm{MMH}$ menstruation/puberty content.

\section{MMH content}

Non-MMH content 


\section{Menstruation Google Trends Search Data}

\section{Search data vs MMH content publication}

Search data specific to menstruation in Togo broadly correlates with MMH topic content, indicating a potential correlation between MMH content and broader search behavior.

However, direct causation cannot be attributed.

Spikes in search activity around menstruation occurred during weeks in which MMH published related content. This was true for $4 / 5$ of the $M M H$

menstruation/puberty posts, as shown.

As seen in Burkina Faso, paid boosting of MMH content in late March coincided with a google search spike, though this could also have been driven by International Women's Day, among other things.

\section{MENSTRUATION SEARCH DATA | TOGO | I NOV 20 I9-3 I JAN 202 I}

100

90

80

70

60

50

40

30

20

Camara's 1 st

0 period vid

0

$11 / 3 / 19 \quad 12 / 3 / 19$

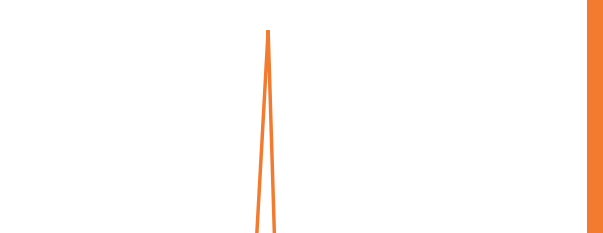

Google Trends search data shows how

frequently a given term is searched for relative to total search volume for a country, over a period of time.

A value of 100 is the peak popularity of the term, whilst a value of 0 means that the term did not register at all during that week, relative to other online searches in the country.

Menstrual Hygiene Day, 28 May 2020

\section{MMH content}

Non-MMH content

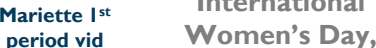
8 March 2020

Menstrual

What you cycle FB

need to

know about

Paid boost of MMH content
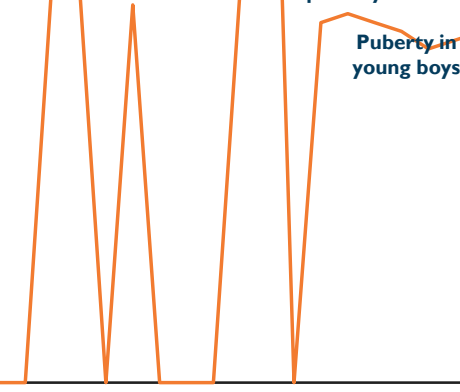
Puberty in young boys
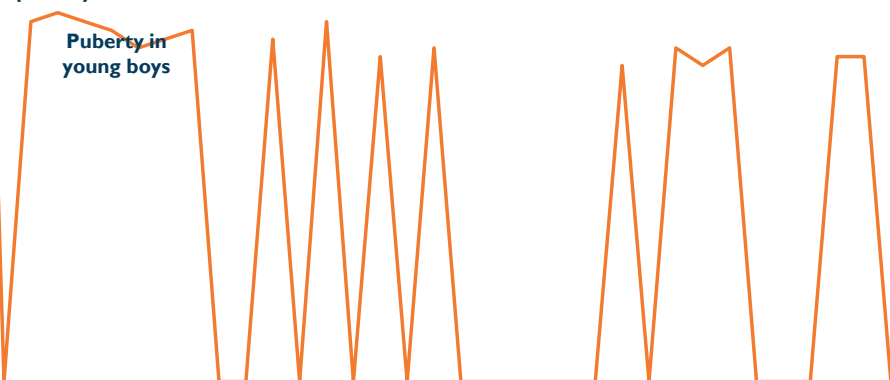

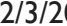

$3 / 3 / 20$

$4 / 3 / 20$

$5 / 3 / 20$

$7 / 3 / 20$

$8 / 3 / 20$ 


\section{Focus on first periods (a key MMH theme) increases by $172 \%$}

\section{First period: Endline vs baseline}

In Togo, the endline review reveals the first periods theme grew by a massive $+172 \%$ to reach $30 \%$.

The analysis shows evidence of people engaging in conversation about their own first period experiences in order to break the taboo around the topic - a goal of the $\mathrm{MMH}$ campaign. This suggests a correlational relationship between the Togo conversation and the MMH campaign content.

However, while the growth in this theme is sizeable, it should be noted that the significant $30 \%$ size of the first period theme has been driven, at least in part, by the strong presence of NGO initiatives in-country.

If the increased engagement can be maintained, the sharing of

individual's stories should continue to grow.

\section{FIRST PERIOD MENTIONS AS A PROPORTION OF} MENSTRUATION/PUBERTY MENTIONS | TOGO | BASELINE VS ENDLINE

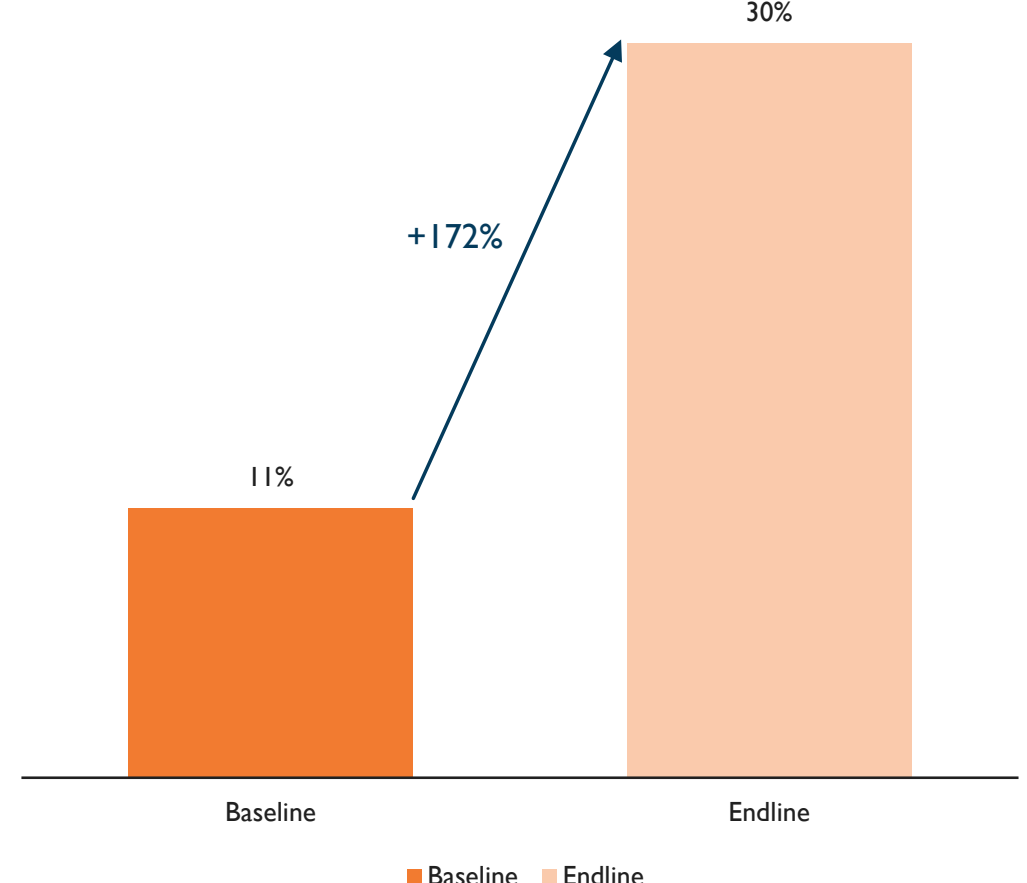

En vacances. Ma tante a dit tu es devenue une femme. Tu peux tomber enceinte à tout moment.

Des mois après maman a dit ce n'est pas parce que tu as couché avec ton cousin que tu as eu tes règles? Je ne connaissais RIEN au sexe en ce moment. Et le gars me harcelait.C'était pénible

perception de la menstruation et des changements qu'elle va vivre. Quels mots as-tu entendu, le jour où tu as eu tes premières règles? Quels mots aurais-tu aimé entendre?

Tous vos témoignages feront l'objet d'un recueil qui sera diffusé, ceci tout en veillant à ce que les

8:20 AM $\cdot 8$ mars 2020

$\mathcal{O} 2 \bigcirc 2 \quad \mathcal{P}$ Copier le lien du Tweet

Ma petite sœur vient d'avoir ses premiers règles elle est en pleure la pauvre, c'est tout nouveau pour elle $\bullet$

2:52 PM $\cdot 5$ oct. 2020 


\section{Pain dialogue grows in size During review period}

\section{Pain: Endline vs baseline}

The baseline report revealed 23\% of Togo posts were tied to the experience of pain. The endline report reveals this theme grew to account for $27 \%$.

As is evident throughout the analysis in all countries, the pain experienced during periods is a dominant theme.

Given the significant emphasis on pain in the dialogue around menstruation/puberty, this offers an obvious route for $\mathrm{MMH}$ to further enhance engagement by producing content that addresses this shared experience.

As noted previously, MMH should consider tailoring messages and videos that encourage adults to support adolescents in managing pain and seeking medical care if symptoms are severe.

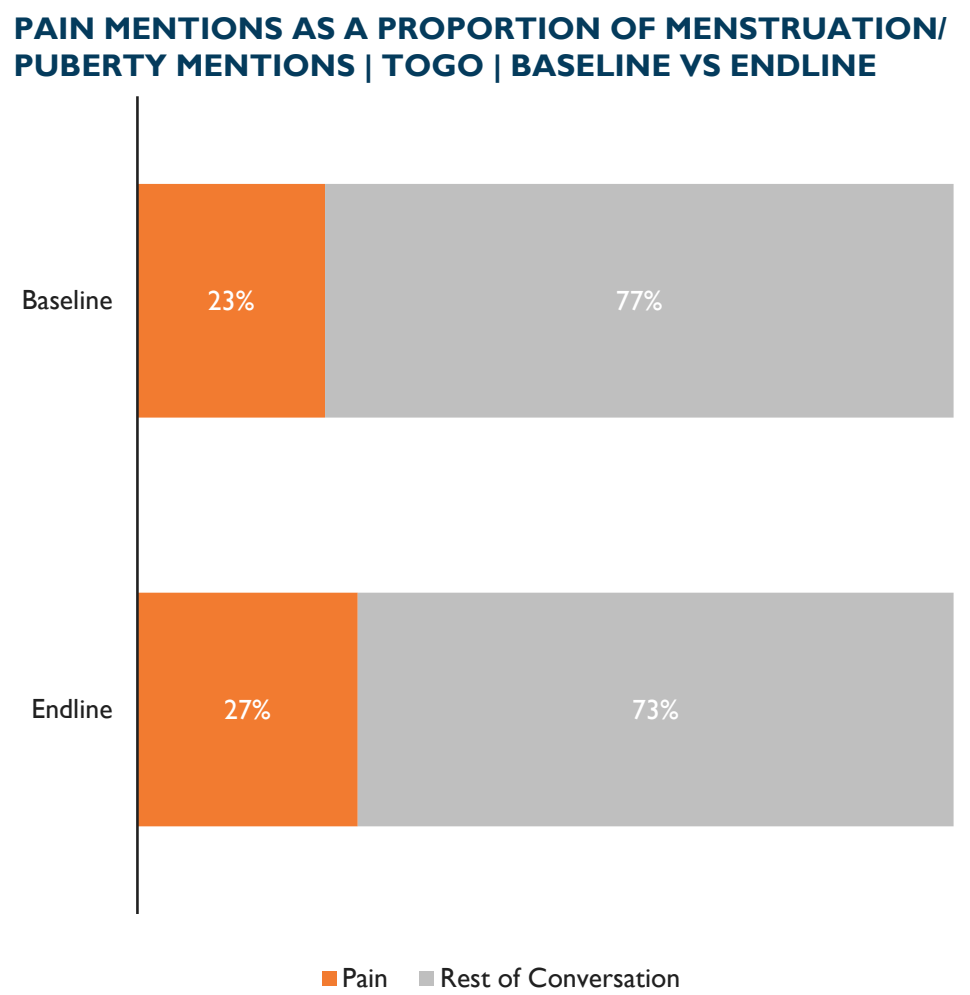

Les règles c'est une souffrance toi seul ta des sauts $d$ humeur ta faimtu vomis pour rien t'a froid ta mal au bas ventre au dos et tu peux pas bouger et pour juste voir une infine tâche. Seigneur yf.

5:11 AM $\cdot 15$ janv. 2021

$\bigcirc 2 \bigcirc 1 \odot$ Copier le lien du Tweet

7 jours de règles

Ça a fais une ptnnn de semaine je saigne..

7 jours

Parfois 2 fois dans le mois j'ai droit a ce même scénario

Mère nature va falloir y aller doucement avec moi..

Jsuis pas un extraterrestre $\equiv \equiv \equiv$

9:31 PM $\cdot 30$ oct. 2020 


\section{Notable increase in replies shows growth in engagement}

\section{Starting conversations: Endline vs baseline}

The Togo analysis reveals the majority of posts in this sub-topic to be driven by shares/retweets of content. However, there was notable growth in both original posts and replies, demonstrating a growing appetite for (and acceptance of) discussion around the topic.

The share of replies grew from $2 \%$ to $5 \%$ during the review period, indicating a positive direction of travel for increasing engagement.

The analysis revealed evidence of male adolescents seeking education on the topic of menstruation, with women engaging them in conversation.

The MMH panel discussion around menstruation achieved cut-through, with the featured tweet achieving $17 \mathrm{k}+$

impressions.
TYPE OF POSTS | MENSTRUATION/ PUBERTY CONVERSATION

BASELINE VS ENDLINE

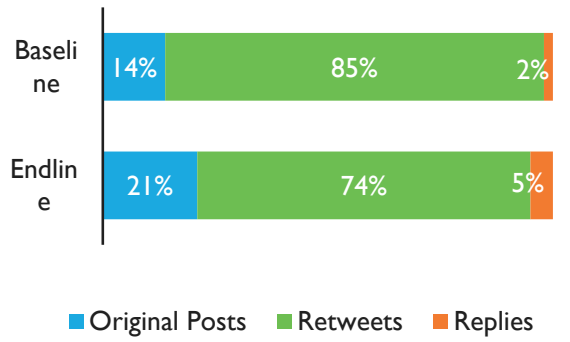

- Original Posts $\quad$ Retweets $\quad$ Replies

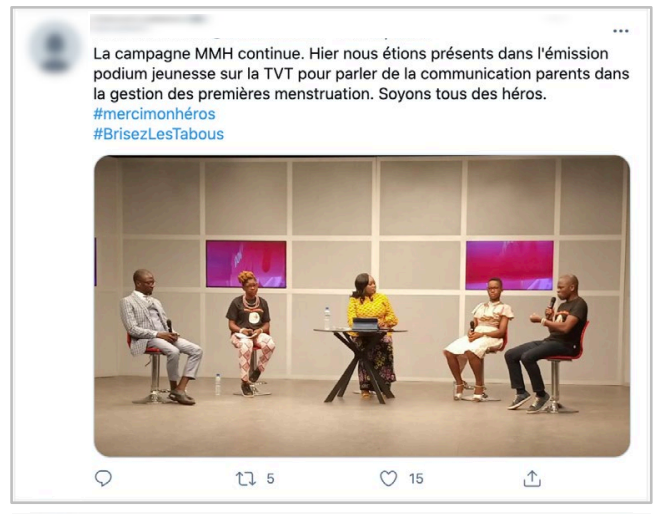

a

La puberté doit faire l'objet d'une discus* entre les parents et I'enfant, selon le Dr Pargade. "Certains adultes se diz que l'éducation se fera par le biais d'une discus* avec les amis de l'eft. Sauf que Is amis, on ne sê pas ce qu'ils ont appris et comment. \#BrisezLesTabous

6:59 AM - 30 mai 2020

$\bigcirc 2 \bigcirc 1 \&$ Copier le lien du Tweet
Thread de question uniquement pour les femmes (mais les gars vous pouvez voir les résultats ) ce thread à pour but de m'édifier sur tout ce que vous pouvez subir au quotidien. Parce que en tant qu'homme je n'ai pas l'impression de bien m'en rendre compte.

Règles douloureuse, ovulation douloureuse, avant et après règles toujours douloureux. Et on a pas le droit de s'absenter au boulot

1:39 AM - 29 janv 2021

$07 \bigcirc 1 \mathcal{S}$ Copier le lien du Tweet

Qu'en était-il, dans l'histoire ? Les hommes ont-ils longtemps ignorés que les menstruations pouvaient être douloureuses ?

Longtemps, je ne sais pas.

Mais les règles douloureuses n'étaient pas si récurrentes. Et celles qui en souffraient gardent le silence. Sujet tabou. Et quand tu dis aussi que tu en souffres, on te classe direct. 3:46 AM - 3 déc. 2020

$\bigcirc 2 Q 2 \&$ Copier le lien du Tweet 


\section{Mention of sisters alongside period increases by $\mathbf{8} \%$ points}

\section{Starting conversations: Endline vs baseline}

The baseline report revealed that mothers were the most prominent support network member and this remained true during the endline review period, though their share of voice fell slightly.

The support network members' share of voice remained largely consistent over review periods, with one statistically significant increase $(p=0.048)$ for sisters, which grew $+8 \%$, reflecting a far greater emphasis placed on the role of sisters/sisterhood in the menstruation conversation during the endline review.

Future content should leverage this learning by championing the role of sisters/sisterhood in learning about menstruation.

\section{SUPPORT NETWORK MENTIONS ALONGSIDE PERIOD DISCUSSIONS | TOGO | BASELINE VS ENDLINE}

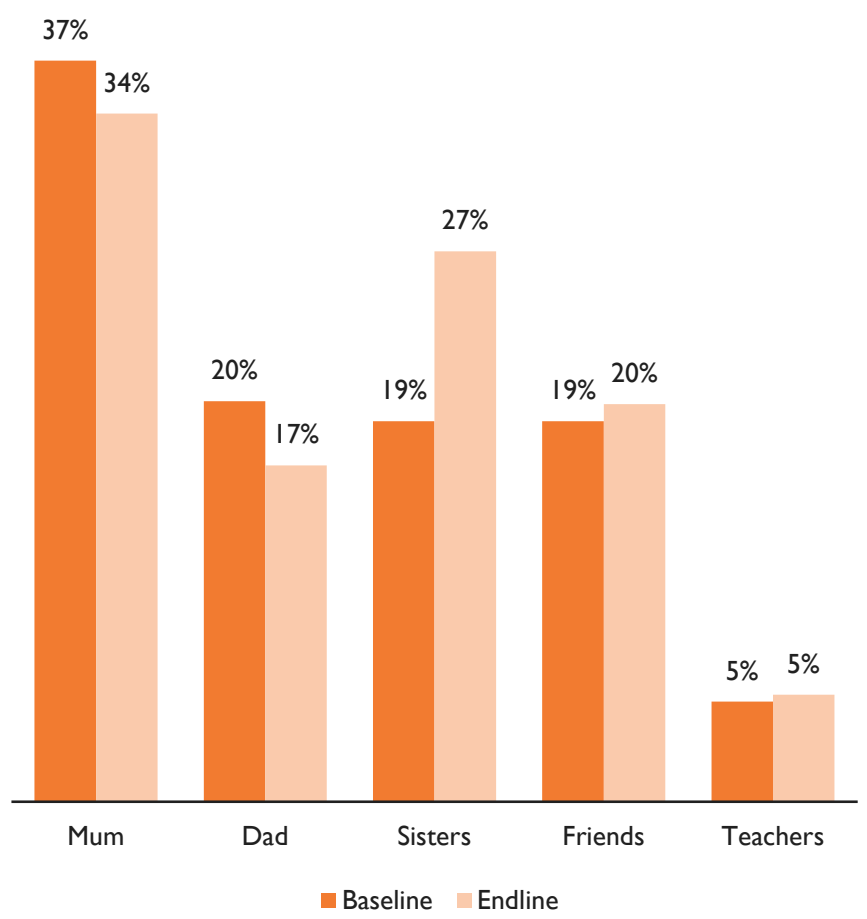

Heureusement ma douleur ne dure que 2 jours sur mes 3 jours de règles $s=$

Soutien aux soeurs qui font une semaine ou plus $\hat{c}$ 7:00 PM $\cdot 28$ mai 2020

$\mathcal{O} 1 \bigcirc 2 \mathcal{O}$ Copier le lien du Tweet

C'est en 2019 que j'ai eu la pire menstruation de toute ma vie. De l'ovulation à la survenue des règles j'ai ressenti des douleurs. Quand elles sont venues je ne pouvais aller nulle part. Ma soeur a dû appeler un ami gynéco qui m'a dit quoi prendre

\#MenstrualHygieneDay2020

1:22 PM · 28 mai 2020 


\section{Niger}

Menstruation/puberty topic 


\section{Headline stats for Niger}

- There were 7I relevant menstruation/puberty topic posts during the 12month baseline review period. This grew to 142 relevant posts during the I4-month endline review period.

- The average weekly volume of relevant menstruation/puberty topic posts in Niger grew from I during baseline to 2 during endline.

- In Niger, there was no discernable/statistical uptick in conversation volume following publication of MMH menstruation/puberty content.

- A reluctance for open dialogue around the topic remains. Any growth in conversation has been driven predominantly by organisations/initiatives (other than MMH-e.g., Unicef), trying to raise awareness of (and engagement with) the conversation.

- The experience of pain associated with menstruation has grown slightly during the review period, accounting for $13 \%$ of mentions (up from II\%). Given the emphasis on pain in the dialogue around menstruation/puberty, this offers an obvious route for $\mathrm{MMH}$ to further enhance engagement by producing content that reflects this experience and encourages the audience to consult a healthcare professional to ensure they are ok.
- The Niger analysis reveals the majority of posts in this sub-topic to be driven by shares/retweets of content, demonstrating a reluctance for open dialogue around the topic in-country. The conversation is dominated by organisations/initiatives/campaigns seeking to spread awareness about menstrual hygiene and puberty. Just I\% of posts are replies, down from $2 \%$ during the baseline report, indicating a continued reluctance to share these personal experiences on open forums. 


\section{Menstruation/puberty overview}

\section{Niger timeline: Endline vs baseline}

The menstruation/puberty subtopic accounted for $12 \%$ of the total Niger RH/FP social

conversation during the endline review period, up from $10 \%$ at baseline.

As in other countries, the conversation peaked on Menstrual Hygiene Day. However, it is worth noting the considerably smaller volume of posts in Niger - a trend continued from the baseline review with a smaller online population likely the driving reason for this, alongside cultural differences as well as extremely high illiteracy rates.

While sub-topic conversation has increased in Niger during the review period, sub-topic engagement still remains extremely limited.

\section{FIRST PERIOD MENTIONS AS A PROPORTION OF MENSTRUATION/PUBERTY MENTIONS | NIGER |}

BASELINE VS ENDLINE

30

20

\section{MMH content}

Non-MMH content Menstrual Hygiene Day, 28 May 2020

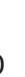

0

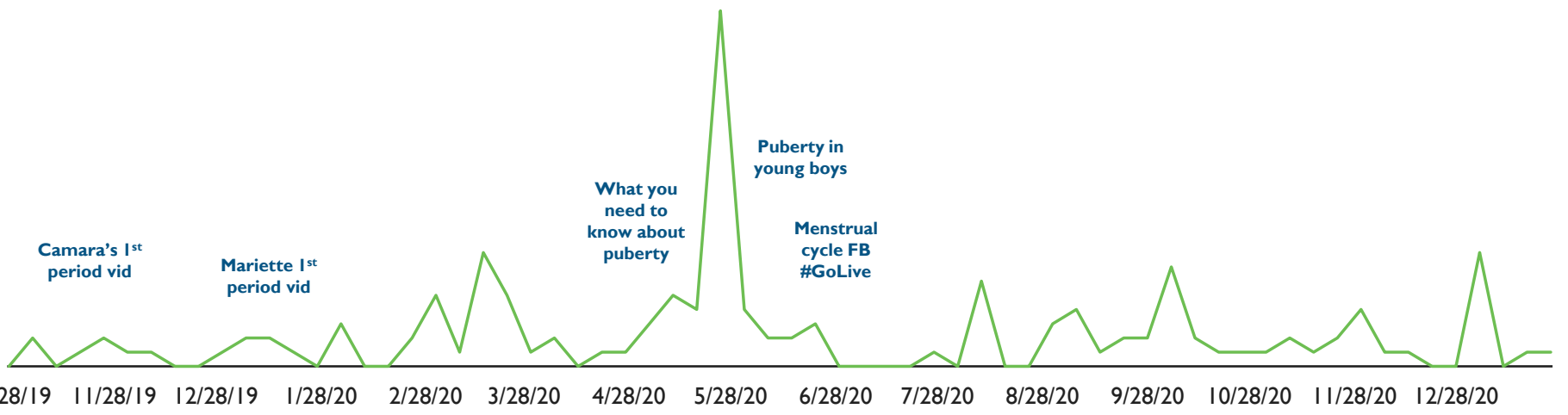




\section{Menstruation Google Trends search data}

\section{Search data vs MMH content publication}

Search data specific to menstruation in Niger shows virtually no correlation to $\mathrm{MMH}$ topic content.

Searches spiked just three times during the review period, with just one of these spikes coinciding with the publication of MMH content.

Given the absence of any discernible uptick in search behavior relating to the other content, it is unlikely that this spike was driven by Mariette's video.

\section{MENSTRUATION SEARCH DATA | NIGER | I NOV 20 I 9-3 I JAN 202 I}

100

90

80

70

60

50

40

30

20

10 Camara's 1 period vid

0

$11 / 3 / 19 \quad 12 / 3 / 19 \quad 1 / 3 / 20$
Mariette $\left.\right|^{\text {st }}$

period vid

0

Google Trends search data shows how frequently a given term is searched for relative to total search volume for a country over a period of time.

A value of 100 is the peak popularity of the term, whilst a value of 0 means that the term did not register at all during that week, relative to other online searches in the country.

MMH content

Non-MMH content 


\section{Focus on first periods (a key MMH theme), increases $\mathbf{8 0 0 \%}$}

\section{First period endline vs baseline}

In Niger, the endline review reveals the first periods them to have grown by a massive $+800 \%$ to reach $9 \%$. While this is extraordinary growth, it should be noted that Niger conversation is extremely limited in volume.

As in Burkina Faso, the growth has been driven predominantly by organisations/initiatives trying to raise awareness of (and engagement with), the conversation. Despite this, a reluctance for open discussion around the topic remains.
FIRST PERIOD MENTIONS AS A PROPORTION OF

MENSTRUATION/PUBERTY MENTIONS | NIGER | BASELINE VS ENDLINE

$9 \%$

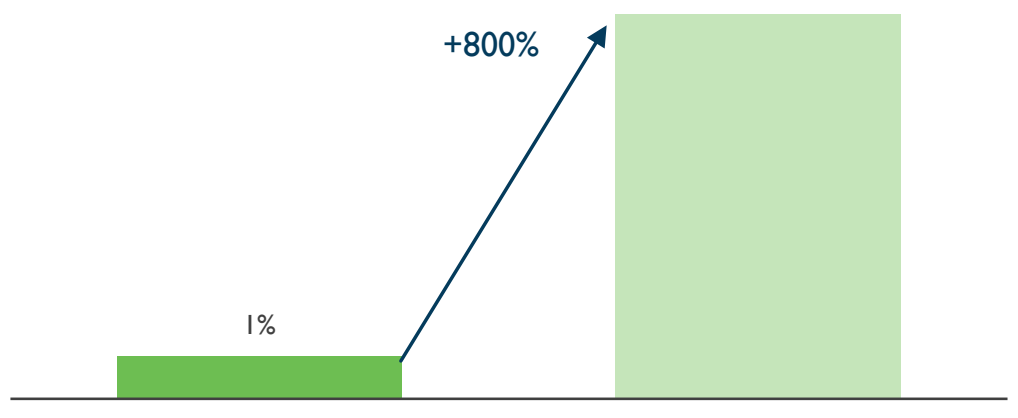

Baseline

Endline
UNICEF $\$$ ๑UNICEF, Jan 20

In Niger, only $30 \%$ of girls have heard about menstruation before their first period.

It's on all of us to break the silence about menstruation and help end
Q 14
七】 153
O 44

Menstruation is a stigmatized topic that people are usually uncomfortable talking about and is only discussed behind closed doors. Let's all step up for our sisters and make this a normal topic like any other. Be period proud

\#herflowmyconcern

@WeOneActionNet2 @unwomenafrica

1:01 PM . Nov 2, 2020 


\section{Rare personal post directly follows MMH content}

\section{First period: Endline vs baseline}

While the Niger conversation is extremely limited at an individual level, one piece of content which did generate some engagement came from the MMH campaign.

One user shared a $\mathrm{MMH}$ video with an excerpt from the video as the caption: "When I had my period, my mother scared me[.] She told me if a boy touched my breasts I was going to get pregnant."

This was a theme identified in the baseline report with numerous women receiving this misinformation from their mothers.
One day after the content was shared another user posted about her similar experience, coinciding with the dissemination of the $\mathrm{MMH}$ content. Niger volume is too low to show any significant correlation.

However, it is worth noting the presence of this tweet given that the campaign encouraged adults to have honest conversations with young people and specifically tried to tackle the

misconceptions and misinformation that exists.
Maman m'a dit "qd tu as tes règles, dès qu'1 garçon te touche, tu $p$ tomber enceinte"

$\mathrm{C}$ I'histoire d Fanta, 1malienne qui a reçu la mauvaise 1 formation sur les règles.

Alors vs, cmt c'était votre 1ère fois? Quelles fausses informations vs avez reçu?

\#MerciMonHéros \#BrisezLesTabous

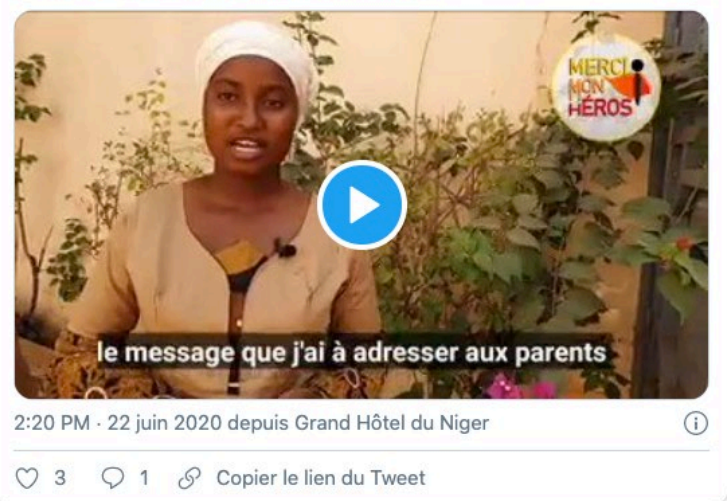

Quand j'ai eu mes règles ma mère elle me fesais peur elle me disait si un garçon me touche les seins j'allais tomber

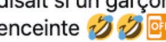

5:55 AM - 23 juin 2020 


\section{Pain dialogue grows slightly during review period}

\section{Pain: Endline vs baseline}

The baseline report revealed II\% of Niger posts were tied to the experience of pain. The endline report reveals this theme to have grown slightly to account for $13 \%$.

As is evident throughout the analysis in all countries, the pain experienced during periods is a dominant theme.

As in the other countries, pain is an element of the discussion around menstruation/puberty in Niger, albeit at a much smaller scale.

Once again, this offers a potential route for $\mathrm{MMH}$ to further enhance engagement by producing content that addresses this shared experience.
PAIN MENTIONS AS A PROPORTION OF MENSTRUATION/ PUBERTY MENTIONS | NIGER | BASELINE VS ENDLINE

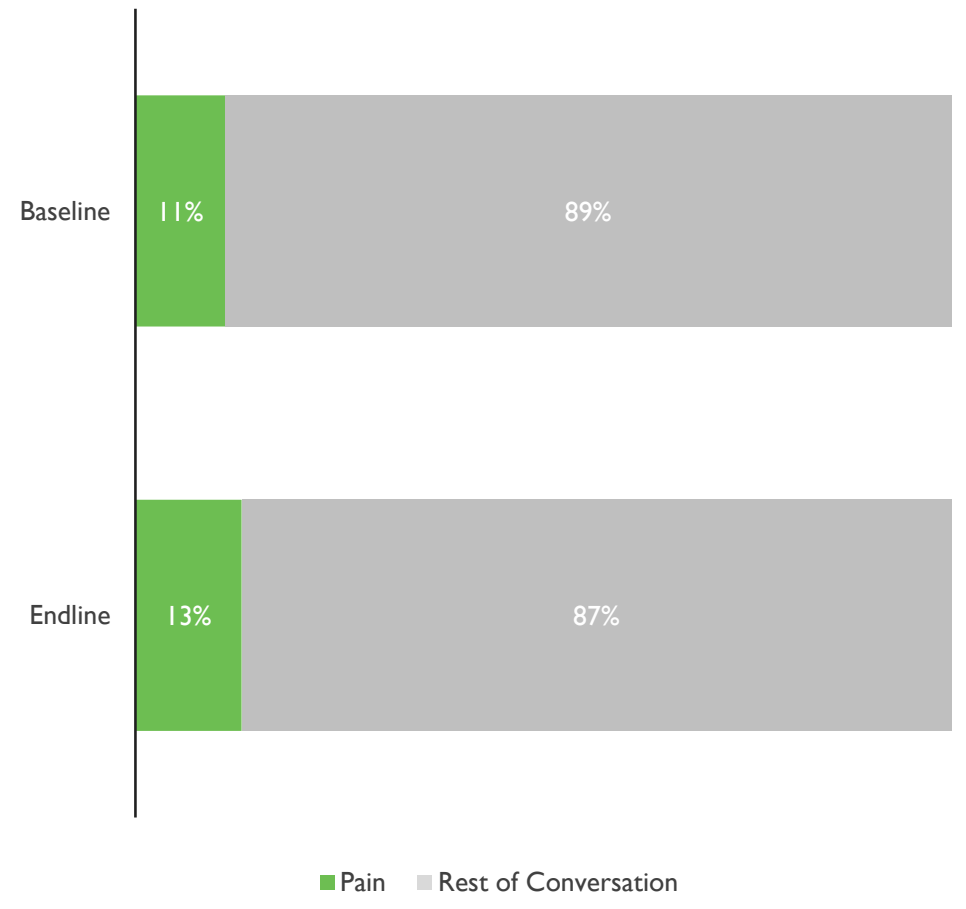

En plus d'avoir des règles douloureuses, certaines filles ont aussi des douleurs au bas ventre pendant la période d'ovulation

12:54 PM - 20 janv. 2021

Quand vous avez des règles douloureuses vous utilisez quoi pour calmez les douleurs ? Rt apprécié ça peut aider

Q 4

१乙 2

○ 1

^

$\varnothing$

ใ】 1

O

乞

Replying to @Ga_Bi_est_laa and @TitaNathalie

Ah je vais dire ça à ma sœur alors parce que c'est surtout elle qui utilise ça parce que c'est le seul qui calme vraiment ses douleurs. Merci pour l'info, moi je suis plus lbuprofène quand j'ai vraiment mal. Mais je n'ai pas de règles si douloureuses.

Translate Tweet

12:31 PM · Nov 6, 2019 - Twitter for iPhone 


\section{Niger conversation still dominated by NGOs and initiatives}

\section{Starting conversations: Endline vs baseline}

The Niger analysis reveals the vast majority of posts in this sub-topic to be driven by shares/retweets of content, demonstrating a reluctance for open dialogue around the topic in-country.

The conversation is dominated by organisations/initiatives/ campaigns seeking to spread awareness about menstrual hygiene and puberty.

It is worth remembering that the conversation volume in Niger is extremely limited, meaning posts that receive shares/retweets easily account for an unequal proportion of conversation.
TYPE OF POSTS FOR "MENSTRUATION PUBERTY" CONVERSATIONS | NIGER | BASELINE VS ENDLINE

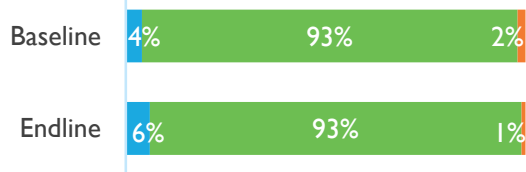

- Original Posts $\square$ Retweets $\square$ Replies

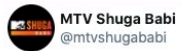

En plus de prévenir la \#grossesse, la pilule peut permettre la régulation de votre cycle, rendre les règles plus légères et moins douloureuses, traiter les saignements utérins dysfonctionnels et les symptômes ovariens polykystiques et l'acné sévère. \#MtvShugaBabi \#MtvShuga

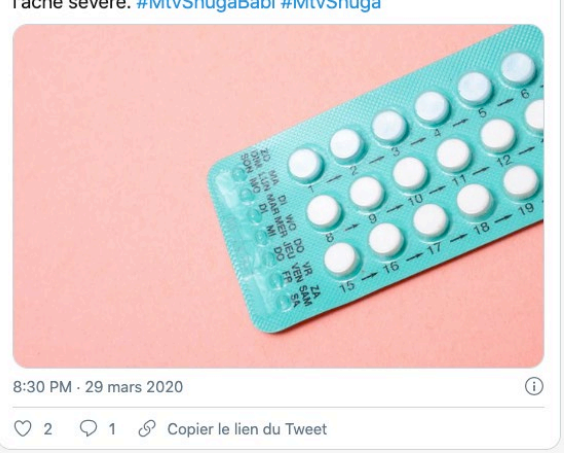

\section{nicerio UNICEF Niger *}

Au Niger 2 , pour beaucoup de jeunes filles, les premières règles marquent une entrée angoissante dans l'adolescence. L'UNICEF travaille avec le gouvernement pour offrir aux filles les moyens de s'attaquer aux idées fausses qui entourent l'hygiène menstruelle.

\section{\#MHDay2020}

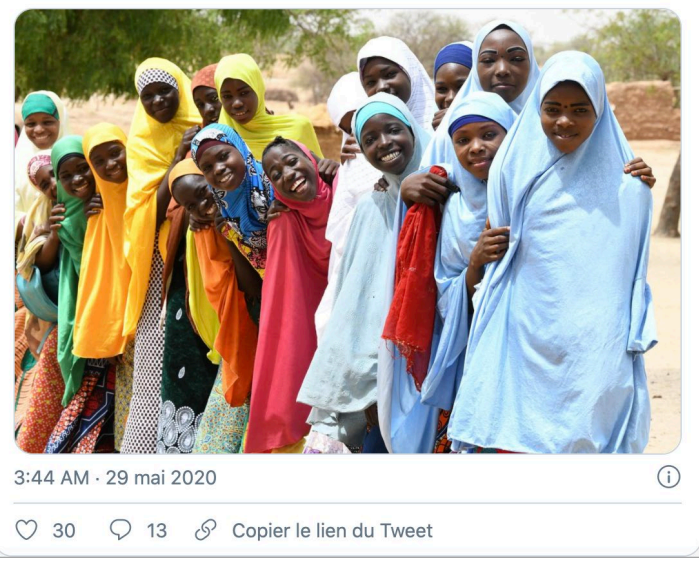


Population Council

4301 Connecticut Ave., NW Suite 280

Washington, DC 20008

+12022379400

breakthroughactionandresearch.org 